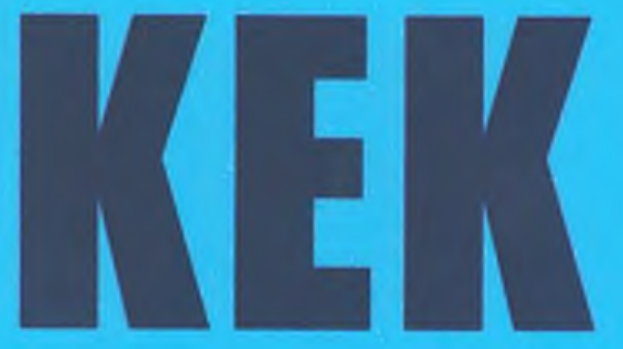

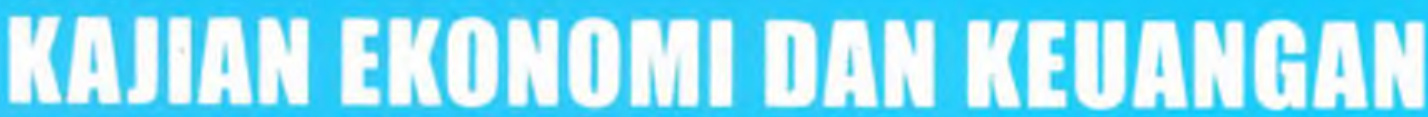

- Analisis Urgensitas Pinjaman Luar Negeri Indonesia Dalam Rangka Pembiayaan Defisit APBN

- Phasing Out Kerosene Subsidy in Developing Countries. Case Study of India and Indonesia

- Kontribusi, Efektivitas, Efisiensi, dan Faktorfaktor yang Mempengaruhi Penerimaan Pajak Pertambahan Nilai

- Studi Potensi Pendanaan Climange Change Pada Lembaga Keuangan Multilateral

- Tax Harmonization ASEAN Melalui ASEAN Tax Forum : Pembelajaran Dari Proses Tax Harmonization Eropa

\begin{tabular}{|c|c|c|c|c|c|}
\hline Kaj. Eko. Keu. & Vol. 16 & No.1 & Jaharta 2011 & $\begin{array}{c}\text { ISSN 1410- } \\
3249\end{array}$ & $\begin{array}{c}\text { Terakreditasi } 8 \\
\text { (No. Akreditasi: } \\
\text { 30B/AU2/P2MBU08/2010) }\end{array}$ \\
\hline
\end{tabular}

Pusat Kebijakan Ekonomi Makro

Badan Kebijakan Fiskal

Kementerian Keuangan

Republlk Indonesia 


\section{K A J I A N}

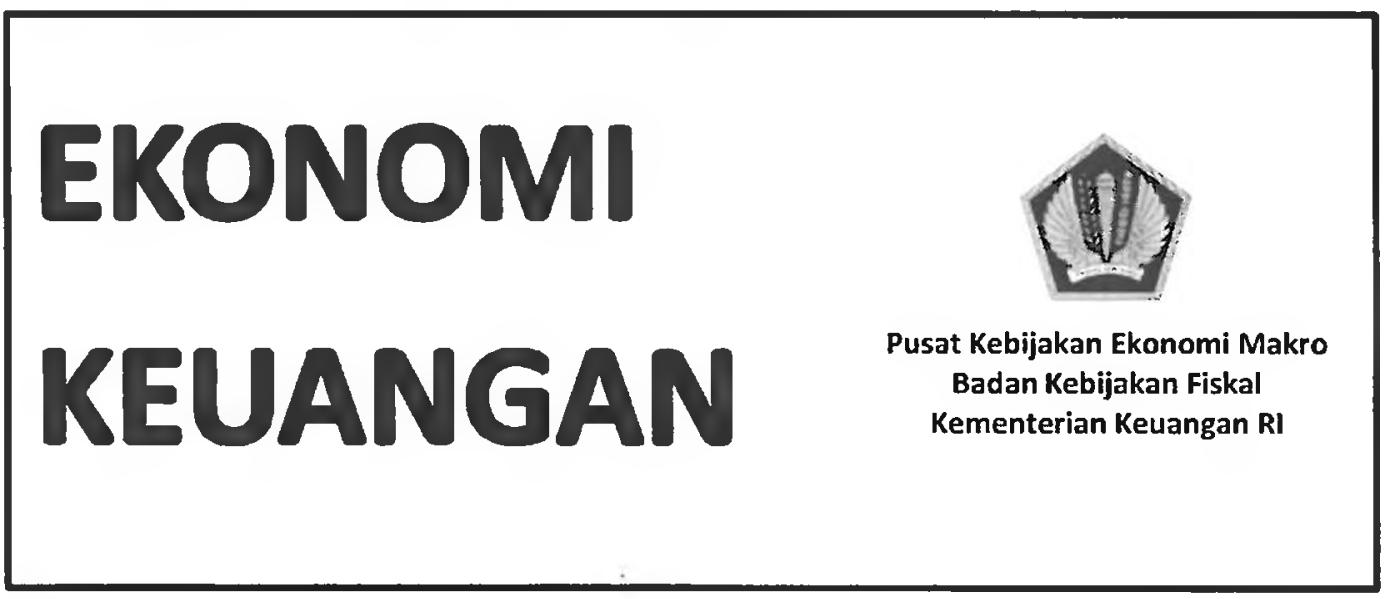

Analisis Urgensitas Pinjaman Luar Negeri Indonesia Dalam

Rangka Pembiayaan Defisit APBN

Phasing Out Kerosene Subsidy in Developing Countries. Case

Study of India and Indonesia

Kontribusi, Efektivitas, Efisiensi dan Faktor-faktor yang

Mempengaruhi Pajak Pertambahan Nilai

Studi Potensi Pendanaan Climate Change Pada Lembaga Keuangan Multilateral

Tax Harmonization ASEAN Melalui ASEAN Tax Forum : Pembelajaran

Dari Proses Tax Harmonization Eropa

\begin{tabular}{|l|l|l|l|l|}
\hline Kaj. Eko. \& Keu. & Vol. 15 & No.1 & Jakarta 2011 & ISSN 1410-3249 \\
\hline
\end{tabular}




\section{KATA SAMBUTAN}

Kami panjatkan rasa syukur kepada Tuhan Yang Maha Esa atas terbitnya Kajian Ekonomi dan Keuangan edisi ini ke hadapan pembaca sekalian. Pada edisi ini, kami menyajikan berbagai topik yang berkaitan dengan analisis dan dampak kebijakan publik di bidang ekonomi dan keuangan negara.

Kajian pada volume kali ini diisi oleh berbagai topik tulisan yaitu Analisis Urgensitas Pinjaman Luar Negeri Indonesia Dalam Rangka Pembiayaan Defisit APBN; Phasing Out Kerosene Subsidy in Developing Countries. Case Study of India and Indonesia; Kontribusi, Efektivitas, Efisiensi, dan Faktor-faktor yang Mempengaruhi Penerimaan Pajak Pertambahan. Nilai; Studi Potensi Pendanaan Climange Change Pada Lembaga Keuangan Multilateral; dan Tax Harmonization ASEAN Melalui ASEAN Tax Forum : Pembelajaran Dari Proses Tax Harmonization Eropa. Adapun para penulis yang berkontribusi pada penerbitan kali ini yaitu Abdul Aziz, Mahpud Sujai, M. Syarif Mulyadi, R. Nurhidajat, Sigit Setiawan, Suska dan Yuventus Effendi.

Demikianlah kata pengantar yang dapat kami sampaikan. Ibarat peribahasa tiada gading yang tak retak, maka kami menyadari kajian ini tentunya masih terdapat kekurangan baik yang disengaja maupun yang tidak kami sengaja. Oleh karena itu, kami mengharapkan masukan dari para pembaca guna perbaikan di masa yang akan datang. Selanjutnya, kami berharap jurnal ini dapat memberikan manfaat kepada para pembaca sekalian. Selamat membaca!

Jakarta, 2011

Dewan Redaksi 


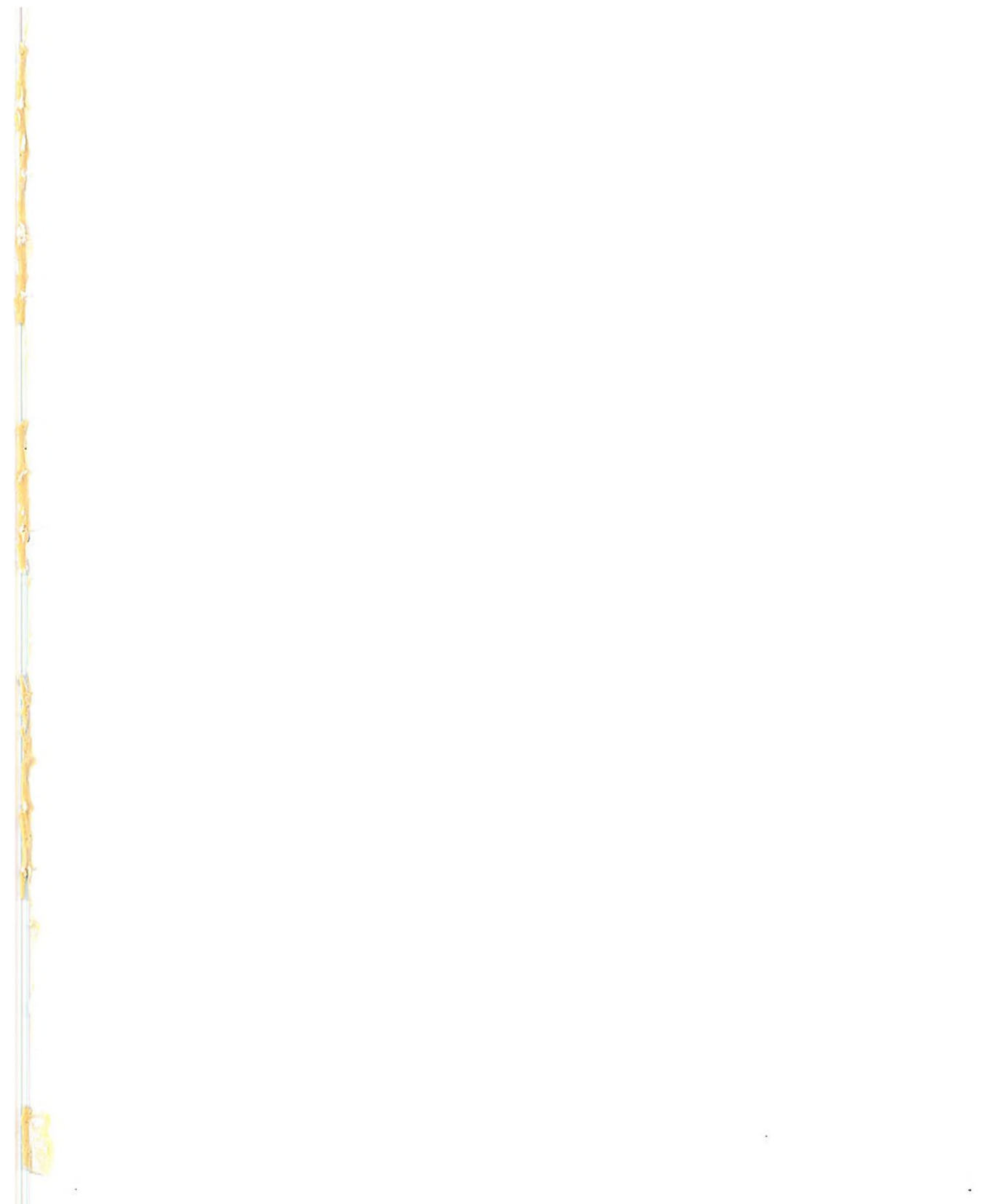




\section{DAFTAR ISI}

\section{Cover}

Dewan Redaksi ................................................................................................................. ii

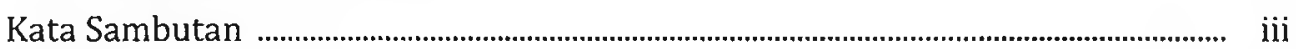

Daftar Isi ............................................................................................................................. $\quad \mathrm{v}$

Daftar Tabel ................................................................................................................. vi

Daftar Gambar .................................................................................................................. vii

Kumpulan Abstraksi ................................................................................................................ ix

ANALISIS URGENSITAS PINJAMAN LUAR NEGERI INDONESIA DALAM RANGKA PEMBIAYAAN DEFISIT APBN

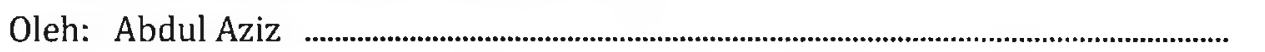

PHASING OUT KEROSENE SUBSIDY IN DEVELOPING COUNTRIES.

CASE STUDY OF INDIA AND INDONESIA

Oleh: Mahpud Sujai

KONTRIBUSI, EFEKTIVITAS, EFISIENSI, DAN FAKTOR-FAKTOR YANG MEMPENGARUHI PENERIMAAN PAJAK PERTAMBAHAN NILAI

Oleh: M. Syarif Mulyadi

Studi Potensi Pendanaan Climange Change Pada Lembaga

Keuangan Multilateral

Oleh: R. Nurhidajat dan Sigit Setiawan

Tax Harmonization ASEAN Melalui ASEAN Tax Forum :

Pembelajaran Dari Proses Tax Harmonization Eropa

Oleh: Suska dan Yuventus Effendi 87 


\section{DAFTAR TABEL}

\section{ANALISIS URGENSITAS PINJAMAN LUAR NEGERI INDONESIA DALAM RANGKA PEMBIAYAAN DEFISIT APBN}

Tabel 2.1. Ringkasan APBN 2001-2009

Tabel 2.2. Perkembangan Penerimaan Negara Pada APBN 2001 s.d. APBN 2009

Tabel 2.3. Perkembangan Belanja Negara Pada APBN 2001 s.d. APBN 2009 .. 7

Tabel 3.1. Penarikan Pinjaman Luar Negeri dan Defisit Anggaran ....................... 12

Tabel 3.2. Penarikan dan Pembiayaan PLN Negara Indonesia Tahun Anggaran 2002 s.d. 2009

Tabel 3.3. Rasio Pembayaran PLN Terhadap Penarikan PLN ................................... 14

Tabel 3.4. Model Dugaan Pinjaman Luar Negeri Indonesia ...................................... 15

Tabel 3.5. White Heteroske da Sticity Test ....................................................................... 16

Tabel 3.6. Correlation Matrix ...................................................................................... 16

Tabel 3.7. Breusch-Godfrey Serial Correlation LM Test .......................................... 17

Tabel 3.8. Pembiayaan Non Utang 2010 dan 2011 .................................................. 25

Tabel 3.9. Perkembangan Pinjaman Pemerintah Negara Indonesia Tahun 1998 dan 2009

PHASING OUT KEROSENE SUBSIDY IN DEVELOPING COUNTRIES.

\section{CASE STUDY OF INDIA AND INDONESIA}

Table 3.1. Fuel Subsidy in India

\section{STUDI POTENSI PENDANAAN CLIMANGE CHANGE PADA LEMBAGA}

\section{KEUANGAN MULTILATERAL}

Tabel 5.1. Distribusi Proyek CDM di Asia Tenggara

\section{TAX HARMONIZATION ASEAN MELALUI ASEAN TAX FORUM :}

\section{PEMBELAJARAN DARI PROSES TAX HARMONIZATION EROPA}

Tabel 2.1. Perkembangan Harmonisasi Pajak Uni Eropa .......................................... 94

Tabel 3.1. Tarif Pajak Tidak Langsung Negara ASEAN ................................................ 95

Tabel 3.2. Tarif Pajak Penghasilan Badan Negara ASEAN ........................................ 96

Tabel 3.3. Daftar Tax Treaty Indonesia dengan Negara ASEAN ............................. 96

Tabel 3.4. Daftar Tax Treaty Antar Negara ASEAN ...................................................... 97

Tabel 3.5. Intra- and Extra-ASEAN Trade, 2009 ........................................................ 98

Tabel 3.6. Rasio Penerimaan Pajak terhada PDB dari Negara Anggota ASEAN Periode 1996-2009 .......................................................................... 99

Tabel 3.7. Tarif Pajak Tidak Langsung Negara Uni Eropa 2004-2009 .................. 100

Tabel 3.8. Tarif Pajak Langsung Negara Uni Eropa1999-2009 ............................... 101 


\section{DAFTAR GAMBAR}

\section{ANALISIS URGENSITAS PINJAMAN LUAR NEGERI INDONESIA DALAM RANGKA PEMBIAYAAN DEFISIT APBN}

Grafik 3.1. Komposisi SUN Tidak Ideal ................................................................. 27

Grafik 3.2. Komposisi SUN Ideal ......................................................................... 27

\section{PHASING OUT KEROSENE SUBSIDY IN DEVELOPING COUNTRIES. CASE STUDY OF INDIA AND INDONESIA}

Picture 3.1. Fuel Subsidy Formula ………………................................................................. 39

Picture 3.2. Kerosene to LPG Conversion Road Map .................................................. 41

Picture 3.3. Consumption Volume of Kerosene and LPG ......................................... 43

Picture 3.4. The Amount of Subsidized Kerosene and LPG ..................................... 43

Picture 3.5. Proportion of Kerosene to LPG Usage ................................................... 44

Picture 3.6. Estimated Amount of Subsidy Diversion in India ................................ 46

KONTRIBUSI, EFEKTIVITAS, EFISIENSI, DAN FAKTOR-FAKTOR YANG MEMPENGARUHI PENERIMAAN PAJAK PERTAMBAHAN NILAI

Grafik 3.1. Tax Ratio (dalam persen) ......................................................................... 60

Grafik 3.2. Perkembangan PDB, Konsumsi Nasional dan Penerimaan PPN (dalam miliar Rp) 61

Grafik 3.3. Peran PPN dan PPh Terhadap Total Penerimaan Perpajakan (dalam persen) 62

Grafik 3.4. Kontribusi Penerimaan PPN dan PPh Dalam Membiayai Belanja Pemerintah(dalam persen) ............................................................. 64

Grafik 3.5. Perkembangan Penerimaan Pajak (dalam miliar rupiah) ................... 65

Grafik 3.6. Kinerja Penerimaan PPN ................................................................................ 66

Grafik 3.7. Potensi dan Realisasi PPN (dalam triliun RP) ......................................... 67

Grafik 3.8. Gap Antara Potensi dan Realisasi PPN (dalam triliun RP) ................. 67

STUDI POTENSI PENDANAAN CLIMANGE CHANGE PADA LEMBAGA KEUANGAN MULTILATERAL

Gambar 3.1 Diagram Mekanisme Kerja CDM

Gambar 6.1 Mobilisasi Pembiayaan Dengan Mekanisme Pasar ................................... 81

TAX HARMONIZATION ASEAN MELALUI ASEAN TAX FORUM : PEMBELAJARAN DARI PROSES TAX HARMONIZATION EROPA 


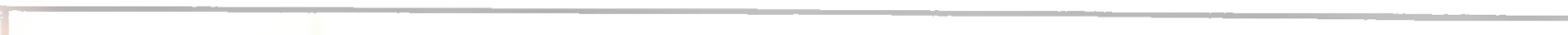




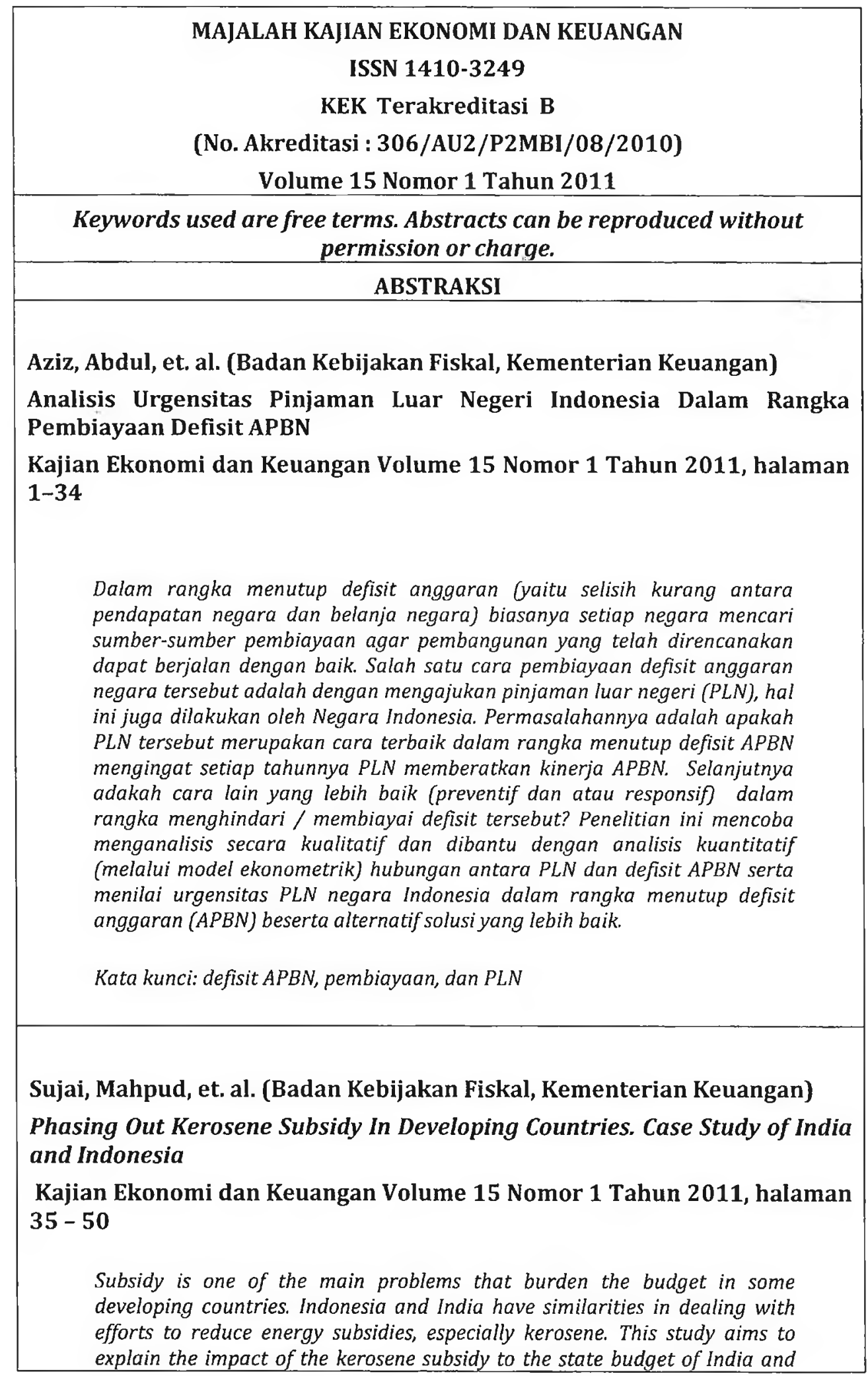




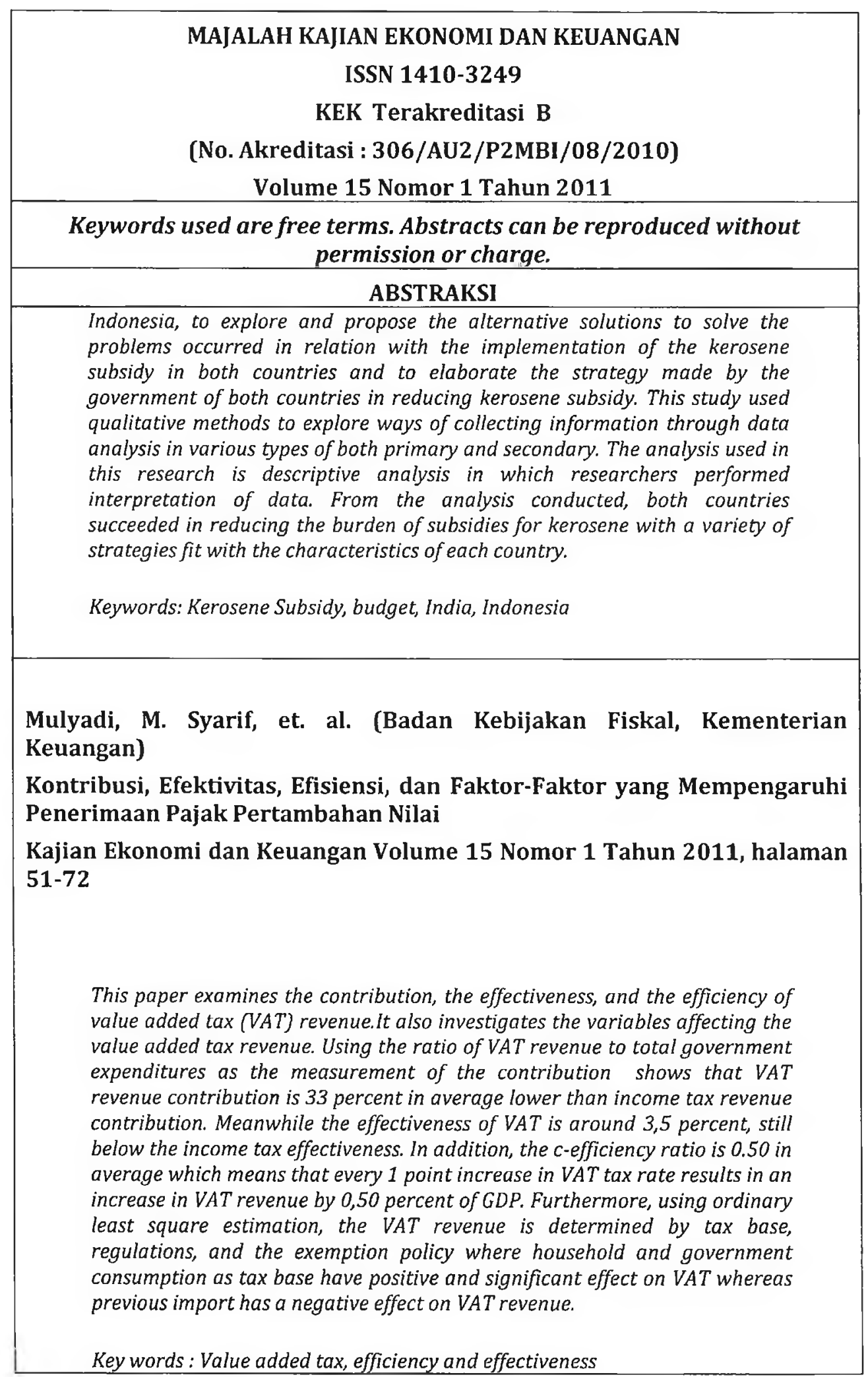




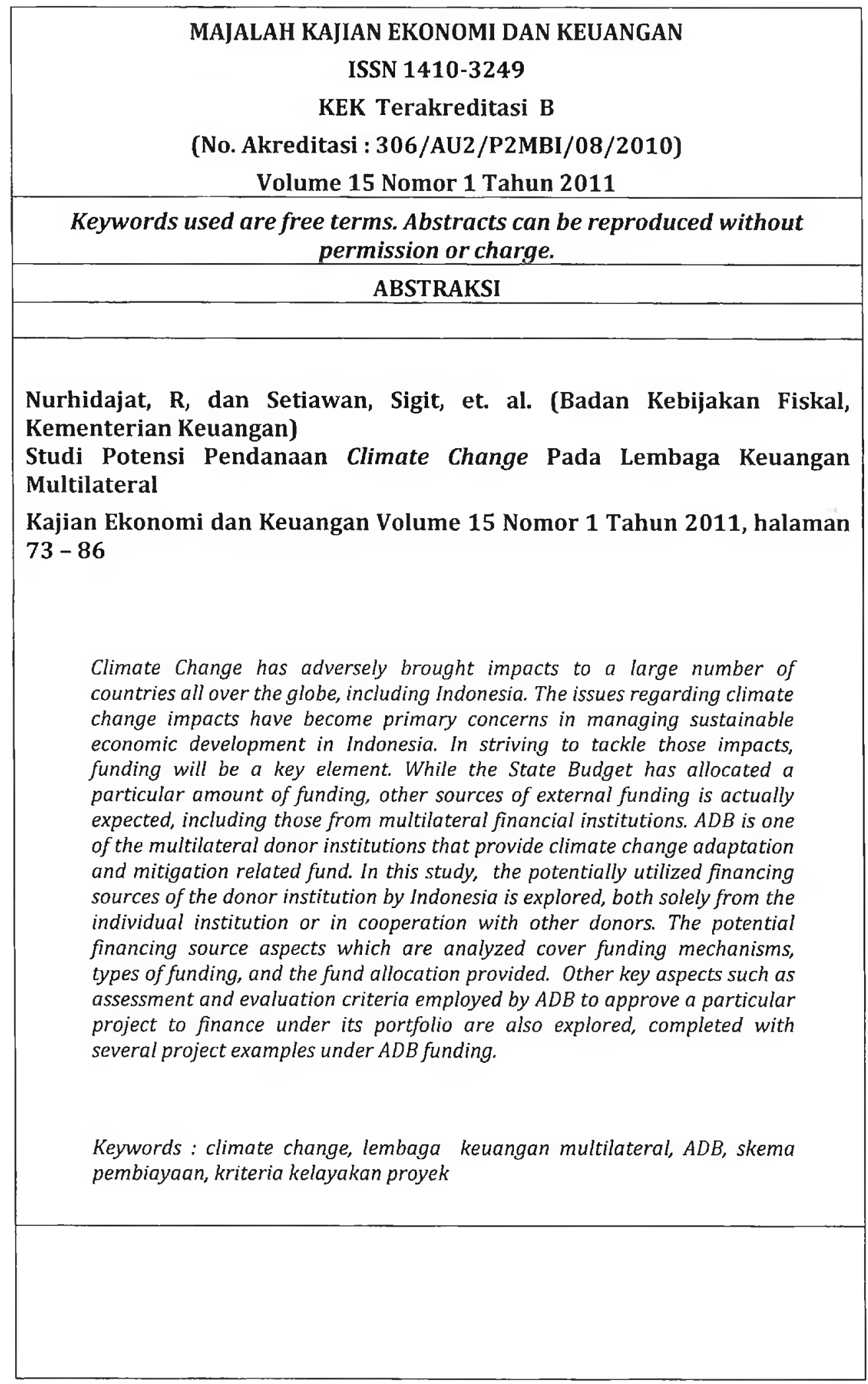




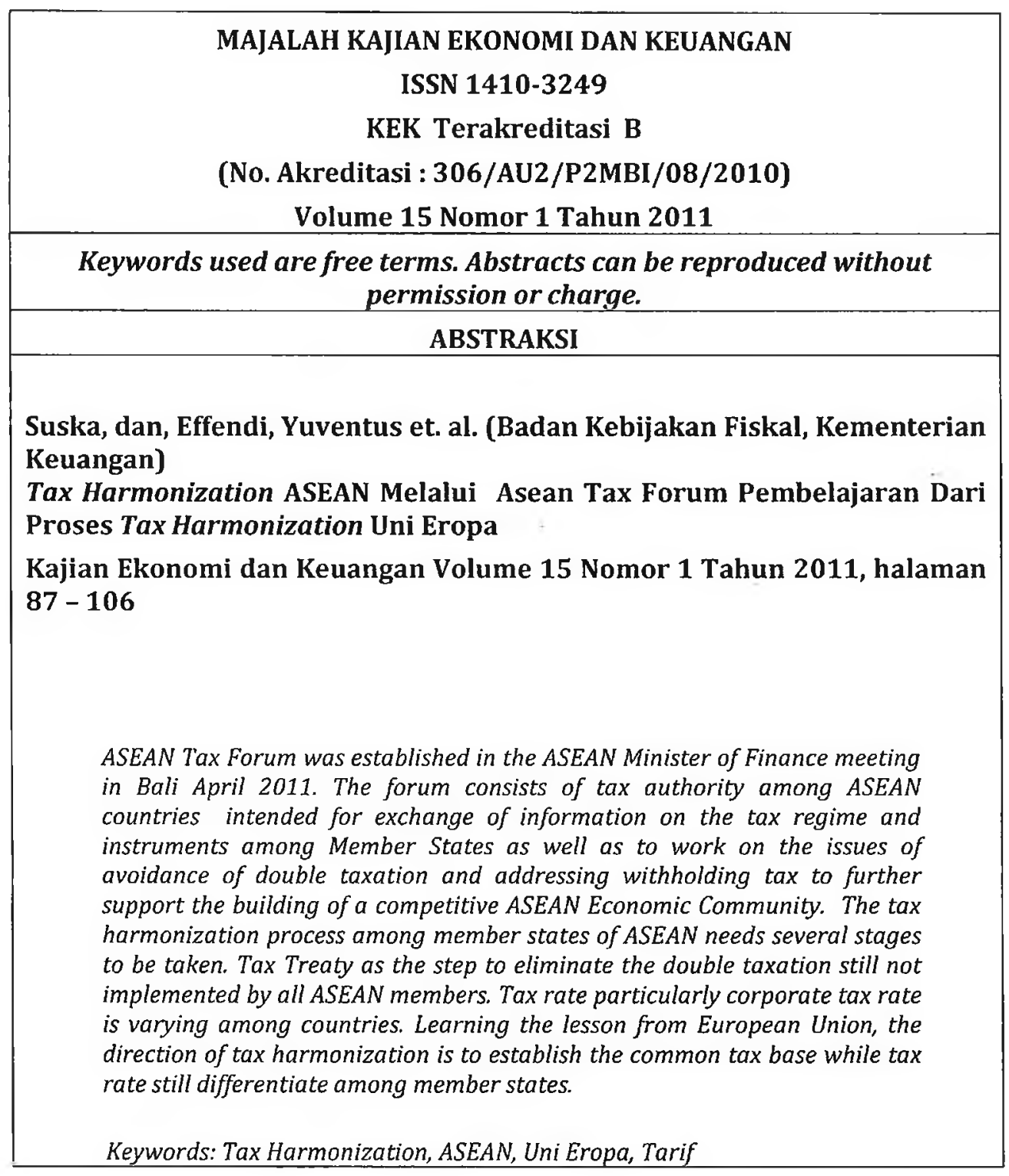




\title{
KONTRIBUSI, EFEKTIVITAS, EFISIENSI, DAN FAKTOR-FAKTOR YANG MEMPENGARUHI PENERIMAAN PAJAK PERTAMBAHAN NILAI
}

Oleh:

M. Syarif Mulyadi ${ }^{1}$

\begin{abstract}
This paper examines the contribution, the effectiveness, and the efficiency of value added tax (VAT) revenue.It also investigates the variables affecting the value added tax revenue. Using the ratio of VAT revenue to total government expenditures as the measurement of the contribution shows that VAT revenue contribution is 33 percent in average lower than income tax revenue contribution. Meanwhile the effectiveness of VAT is around 3,5 percent, still below the income tax effectiveness. In addition, the c-efficiency ratio is 0.50 in average which means that every 1 point increase in VAT tax rate results in an increase in VAT revenue by 0,50 percent of GDP. Furthermore, using ordinary least square estimation, the VAT revenue is determined by tax base, regulations, and the exemption policy where household and government consumption as tax base have positive and significant effect on VAT whereas previous import has a negative effect on VAT revenue.
\end{abstract}

Key words : Value added tax, efficiency and effectiveness

\section{PENDAHULUAN}

\subsection{Latar Belakang}

Di hampir seluruh negara termasuk Indonesia, pajak memiliki peranan yang sangat strategis, baik sebagai sumber penerimaan negara maupun sebagai instrumen kebijakan pemerintah dalam mempengaruhi alokasi sumber-sumber daya ekonomi dan mengurangi konsumsi masyarakat (swasta) atas barang dan jasa (Lindohlm, 1970). Di Indonesia, peranan penerimaan pajak semakin penting sebagai sumber penerimaan negara terutama setelah berakhirnya era oil boom, yang ditandai dengan menurunnya penerimaan negara dari migas. Sejalan dengan meningkatnya belanja pemerintah untuk mencapai berbagai tujuan pembangunan,

\footnotetext{
1 Penulis adalah calon peneliti pada Badan Kebijakan Fiskal, Kementerian Keuangan. Ucapan terimakasih kepada rekan-rekan peserta Diklat Fungsional Peneliti Tk Pertama, angk. 22 tahun 2010 terutama untuk Sdr. Afdi Nizar dan Slamet Widodo atas bahan masukannya.
} 
penerimaan pajak merupakan sumber utama disamping berbagai sumber penerimaan lainnya seperti hutang baik dalam negeri maupun luar negeri.

Salah satu jenis penerimaan pajak adalah pajak pertambahan nilai (PPN) atau value added tax (VAT). PPN dikenakan pada nilai tambah dalam proses produksi barang/jasa pada berbagai tahapan produksi suatu barang/jasa (Sukardji, 2003). Pada awalnya pengenaan PPN bukan ditujukan untuk meningkatkan peneriman pajak, akan tetapi sebagai bentuk pengganti pajak lain (pajak penjualan/PPn) yang memiliki kelemahan dimana kelemahan tersebut tidak dimiliki oleh jenis PPN (Shoup, 1988). Penggantian PPn menjadi PPN tersebut ditetapkan melalui UndangUndang Nomor 8 Tahun 1983 tentang Pajak Pertambahan Nilai. Dalam perkembangannya, UU PPN tersebut mengalami beberapa kali perubahan, terakhir adalah UU No 42 tahun 2009.

Sejak diberlakukannya Undang-undang tentang PPN tersebut, peranan PPN sebagai sumber penerimaan negara dari waktu ke waktu terus menunjukkan peningkatan. Kontribusi penerimaan PPN mengalami perubahan seiring dengan terjadinya perubahan dalam tax base-nya (baik dilihat dari sisi produksi maupun konsumsi). Di samping itu, penerimaan tersebut juga dipengaruhi oleh tarif dan berbagai kebijakan seperti kebijakan pengecualian perpajakan/tax exemption. Dengan asumsi tingkat PPN tetap, kontribusi penerimaan PPN dalam membiayai anggaran belanja negara dipengaruhi oleh perubahan tax base dan banyaknya kebijakan tax exemption.

Kinerja penerimaan PPN selain dilihat dari kontribusinya juga dapat dilihat dari efektivitas dan efisiensinya. Meskipun secara nominal penerimaan PPN meningkat terus-menerus, namun tidak berarti efektivitas dan efisiensi juga meningkat secara otomatis. Pada saat tax base semakin besar, sangat wajar apabila penerimaan PPN juga meningkat sehingga hal tersebut tidak berarti menunjukkan peningkatan efisiensi PPN. Penelitian dalam paper ini membahas penerimaan PPN dilihat dari kontribusinya dalam membiayai anggaran belanja negara, efektivitas, dan efisiensinya.

\subsection{Perumusan Masalah}

Berdasarkan uraian tersebut diatas, perumusan masalah dalam penelitian ini adalah sebagai berikut :

1. Seberapa besar tingkat kontribusi penerimaan PPN dalam membiayai anggaran belanja pemerintah?

2. Seberapa besar tingkat efektivitas dan efisiensi penerimaan PPN ?

3. Faktor-faktor apa saja yang mempengaruhi penerimaan PPN ? 


\subsection{Tujuan Penelitian}

Berdasarkan perumusan masalah penelitian diatas, maka tujuan penelitian ini adalah:

1. Untuk mengetahui tingkat kontribusi PPN dalam membiayai anggaran belanja negara.

2. Untuk mengetahui tingkat efektivitas dan efisiensi penerimaan PPN.

3. Untuk mengetahui faktor-faktor yang mempengaruhi penerimaan PPN.

\subsection{Tinjauan Pustaka}

\subsubsection{Pengertian dan Karakteristik Pajak Pertambahan Nilai}

Secara sederhana, para ahli mendefinisikan pajak sebagai iuran wajib yang dipaksanakan oleh pemerintah kepada masyarakat untuk keperluan pendanaan kegiatan pemerintah. Menurut Pro.Dr.P.J.A. Adriani dalam Waluyo (2005:2), pajak adalah "iuran kepada negara (yang dapat dipaksakan) yang terutang oleh yang wajib membayarnya menurut peraturan, dengan tidak mendapat prestasi kembali, yang langsung dapat ditunjuk dan yang gunanya untuk membiayai pengeluaran umum berhubungan dengan tugas negara yang menyelenggarakan pemerintahan".

Sementara pajak pertambahan nilai (PPN) atau value added tax (VAT) diartikan sebagai pajak yang dibebankan atas nilai tambah, yang merupakan perbedaan antara nilai penjualan perusahaan dengan nilai input yang dibeli yang digunakan untuk memproduksi barang (Hossain, 1995). Dengan kata lain, PPN adalah pajak yang dikenakan atas nilai yang ditambahkan suatu perusahaan terhadap sesuatu yang dibeli dari perusahaan lain untuk menghasilkan suatu produk. Sebagai contoh petani gandum menjual hasil gandumnya ke penggilingan gandum. Dari penggilingan gandum akan dihasilkan produk tepung gandum. Sampai tahap ini, terjadi perubahan produk dan penambahan nilai yang semula gandum menjadi tepung gandum. Proses selanjutnya gandum yang dijual akan digunakan oleh pabrik roti untuk membuat roti, terjadi pertambahan nilai lagi. Pabrik roti menjual produknya ke perusahaan retail dimana perusahaan retail akan mengemas roti sedemikian rupa sehingga kemasannya menarik pembeli. Juga, sampai di sini terjadi perubahan produk dan pertambahan nilai. Keseluruhan proses dari gandum menjadi roti di pengecer mengalami pertambahan nilai beberap kali. Dari setiap pertambahan nilai tersebut akan dikenakan PPN. Nilai total yang berupa roti di pengecer (biaya roti ) hingga ke konsumen merupakan jumlah dari semua tambahan nilai tersebut. Dengan demikian, pajak yang berkaitan dengan masing-masing nilai tambah tersebut dijumlahkan hingga pajak sama dengan yang dikenakan atas nilai penjualan final (Shoup, 1988).

Sukardji (2003) mengemukakan beberapa karakteristik sebagai berikut : 
1. Pengenaan PPN yang merupakan jenis pajak tidak langsung (indirect tax) didasarkan pada transaksi (transaction-based tax). Karena sifat tersebut, maka dalam PPN beban pajak (tax burden) berbeda dengan penanggung jawab atas pembayaran pajak. Beban pajak ditanggung oleh konsumen/pembeli barang/jasa kena pajak yaitu orang yang menerima penyerahan barang/jasa tersebut. Beban tersebut dalam bentuk harga yang lebih tinggi.

2. Pengenaan PPN bersifat obyektif yaitu didasarkan pada keadaan, peristiwa, atau perbuatan hukum yang dapat dikenakan pajak (objek pajak). Dalam hal ini pengenaan PPN tidak membedakan antara konsumen/pembeli berupa orang atau badan. Selain itu, tidak membedakan antara konsumen berpenghasilan tinggi atau berpenghasilan rendah, sepanjang konsumen tersebut melakukan pembelian atas barang/jasa kena pajak maka akan dikenakan PPN.

3. Pengenaan PPN bersifat multi stage tax yaitu dikenakan pada setiap mata rantai kegiatan produksi dan distribusi barang/jasa kena pajak. Setiap penyerahan barang yang menjadi objek PPN mulai dari tingkat pabrikan (manufacturer) kemudian di tingkat pedagang besar (wholesaler) dalam berbagai bentuk atau nama sampai ke tingkat pedagang pengecer (retailer) dikenakan PPN.

4. PPN adalah pajak atas konsumsi umum dalam negeri. Maksudnya adalah PPN dikenakan atas barang/jasa kena pajak yang diproduksi/konsumsi di dalam negeri bukan barang/jasa yang diproduksi di luar negeri. Orang asing yang melakukan pembelian atas barang/jasa kena pajak di Indonesia maka akan dikenakan PPN.

5. PPN bersifat netral. Netralitas PPN ditentukan oleh dua faktor : (i) PPN dikenakan atas konsumsi barang dan jasa; dan (ii) dalam pemungutannya menganut prinsip tempat tujuan (destination principle), yaitu di tempat barang atau jasa dikonsumsi.

6. Pengenaan PPN menghindari pengenaan pajak berganda karena pengenaannya hanya terhadap setiap pertambahan nilai yang timbul pada setiap penyerahan barang/jasa pada jalur perusahaan berikutnya, dengan cara mengkreditkan PPN yang dibayar pada mata rantai sebelumnya (credit method atau indirect substraction method). Pertambahan nilai itu sendiri timbul karena dipakainya faktor-faktor produksi pada setiap jalur perusahaan dalam menyiapkan, menghasilkan, menyalurkan dan memperdagangkan barang atau pemberian pelayanan jasa kepada para konsumen.

7. PPN dihitung dengan metode pengurangan tidak langsung (indirect subtraction), yaitu dengan memperhitungkan besaran pajak masukan dan pajak keluaran. Yang dimaksud dengan pajak keluaran (output tax) adalah Pajak Pertambahan Nilai yang terjadi ketika Pengusaha Kena Pajak ( PKP) menjual suatu barang atau jasa, sedangkan pajak masukan (input tax) adalah Pajak 
Pertambahan Nilai yang terjadi ketika Pengusaha Kena Pajak ( PKP) membeli, memperoleh atau membuat suatu barang atau jasa.

\subsubsection{Kelebihan dan Kelemahan Pajak Pertambahan Nilai}

Berdasarkan uraian karakteristik tersebut diatas, tampak bahwa jenis PPN mempunyai beberapa kelebihan. Beberapa kelebihan PPN adalah :

1. Mencegah terjadinya pengenaan pajak berganda.

2. Netral dalam perdagangan dalam dan luar negeri.

3. PPN atas perolehan barang modal dapat diperoleh kembali pada bulan perolehan sesuai dengan tipe konsumsi (consumption type VAT) dan metode pengurangan tidak langsung (indirect subtraction method). Dengan demikian sangat membantu likuiditas perusahaan.

4. PPN dapat dijadikan sebagai "money maker" dalam penerimaan negara, karena konsumen selaku pemikul beban pajak tidak merasa dibebani oleh pajak sehingga mudah memungutnya.

Selain itu, tingkat tarif pajak PPN yang ditetapkan seragam (misal sebesar 10 persen berlaku untuk semua barang/jasa kena pajak di Indonesia) lebih memudahkan dalam pemungutannya bila dibandingkan tarif bervariasi. Disamping itu, terhadap barang ekspor yang dikenakan tarif PPN sebesar 0 persen relatif lebih memudahkan karena tidak melibatkan perhitungan atas kegiatan proses produksi ekspor. Selanjutnya, penggunaan metoda kredit dalam perhitungan PPN dan mekanisme yang sederhana memudahkan pembayar pajak dalam melakukan pembayaran. (Brondolo J, et.al, 2008).

Meskipun penerapan PPN memiliki kelebihan/keunggulan, namun dalam pelaksanaan masih terdapat beberapa permasalahan yang menyulitkan proses administrasi (Brondolo J, et.al, 2008), seperti proses legal dimana untuk seluruh pengembalian PPN (refund claims) diperlukan proses audit/pemeriksaan terlebih dahulu sebelum dilakukan pengembalian pembayaran dalam waktu 1 tahun. Ketentuan ini mengesampingkan tingkat kepatuhan wajib pajak, baik wajib pajak tersebut memiliki catatan kepatuhan yang sangat baik atau tidak tetap akan dilakukan proses audit. Proses ini sering kali memerlukan waktu lama sehingga akan mempengaruhi arus kas perusahaan terutama perusahaan yang melakukan kegiatan eskpor. Sedangkan bagi kantor pajak, ketentuan ini memerlukan penempatan sumber-sumber seperti tenaga SDM dan dana yang relatif besar. Akibatnya, kantor pajak mengalami kekurangan sumber daya untuk kegiatan lainnya. Berikutnya, adanya daerah tertentu yang bebas PPN seperti di Batam sulit dilaksanakan dan menimbulkan resiko yang signifikan terhadap hilangnya penerimaan PPN serta sangat rawan dari upaya penyelundupan.

Penerapan PPN makin banyak diadopsi oleh banyak negara selain untuk meningkatkan penerimaan negara dalam bentuk pajak, juga untuk mengganti 
penerapan pajak penjualan yang mengalami kelemahan. Kelemahan yang terdapat dalam pajak penjualan dapat diminimalisir dengan mengganti jenis PPN. Lindholm (1970) mengidentifikasi beberapa pertimbangan suatu negara menerapkan PPN, sebagai berikut:

a. dengan diberlakukannya PPN sebagai pengganti pajak langsung (direct tax) selain Pajak Penghasilan ( $\mathrm{PPh}$ ) perorangan, PPh badan, atau pajak properti, maka beban relatif para penabung dan pengguna real estate akan berkurang.

b. jumlah tax evasion menurun sehingga penerimaan pajak meningkat.

c. PPN memiliki karakteristik anti-evasion yang bersifat integral. Karena PPN yang dihitung pada setiap faktur (invoice) menjadi pengurang bagi utang pajak (tax liabilities] para pembeli yang jatuh ke tangan konsumen akhir. Oleh sebab itu, kegagalan membayar PPN oleh penjual akan menambah utang pajak para pembeli barang dan jasa.

d. PPN memperkuat administrasi PPh perorangan dan pajak laba perusahaan (corporate profit tax).

\subsubsection{Dampak Penerapan Pajak Pertambahan Nilai}

Penerapan PPN memberikan manfaat terhadap upaya stabilisasi ekonomi. Sebagai sumber penerimaan negara, PPN memiliki stabilitas yang relatif lebih tinggi, sehingga dalam jangka panjang memberikan kontribusi yang lebih besar dalam rangka kebijakan stabilisasi otomatis (automatic stabilizers) dibandingkan pajak penghasilan. Manfaat stabilisasi lainnya dari PPN adalah efektivitasnya dalam mengurangi pengeluaran konsumsi (Lindohlm, 1970). Selain itu, PPN juga berpengaruh terhadap pertumbuhan ekonomi dan investasi.

Di Indonesia, PPN adalah pajak atas konsumsi barang kena pajak (BKP) dan atau jasa kena pajak (JKP) yang dilakukan di dalam daerah pabean. Yang dimaksud dengan daerah pabean adalah wilayah Republik Indonesia yang didalamnya berlaku Undang-Undang Nomor 10 tahun 1995 tentang Kepabeanan. Secara struktural menurut tarifnya, PPN menganut sistem tarif proporsional ( $a$ proportional tax rate structure) atau tarif tunggal (seragam) yaitu sebesar 10 persen. Maksudnya adalah semua jenis transaksi yang dikenakan PPN tarifnya adalah sebesar 10 persen, kecuali untuk ekspor BKP dengan 0 persen.

Pada dasarnya semua barang dan jasa merupakan barang kena pajak (BKP) dan jasa kena pajak (JKP), sehingga dikenakan PPN, kecuali jenis barang dan jenis jasa sebagaimana ditetapkan dalam Pasal 4A Undang-Undang Nomor 8 Tahun 1983 tentang Pajak Pertambahan Nilai Barang dan Jasa dan Pajak Penjualan Atas Barang Mewah sebagaimana terakhir diubah dengan Undang-Undang Nomor 18 Tahun 2000 tidak dikenakan PPN, diantaranya (i) barang hasil pertambangan atau hasil pengeboran yang diambil langsung dari sumbernya, seperti minyak mentah, gas bumi, dan batu bara; (ii) barang-barang kebutuhan pokok yang sangat 
dibutuhkan oleh masyarakat, seperti beras dan gabah; (iii) segala jenis jagung, sagu kedelai, garam, makanan dan minuman yang disajikan di hotel restoran; (iv) jasa di bidang pelayanan kesehatan, seperti jasa dokter; (v) jasa di bidang pelayanan sosial; (vi) jasa di bidang pengiriman surat dengan perangko, dan sebagainya.

Berdasarkan mekanisme pemungutan, PPN di Indonesia dipungut menggunakan tiga metode, yaitu (Nasution, 2007):

1. Metode Pengurangan Tidak Langsung (indirect substraction method), dimana pengusaha kena pajak yang melakukan penyerahan BKP atau JKP sebagai subjek pajaknya.

2. Metode memungut, menyetor, dan melaporkan sendiri PPN yang terutang atas impor BKP yang disebut self imposition method;

3. Indirect Substraction Method dengan pemungut PPN yang membayar atas penyerahan BKP atau JKP oleh PKP rekanan sebagai subjek pajaknya.

\subsubsection{Efektivitas dan Efisiensi Pajak Pertambahan Nilai}

Teori dasar mengenai keuangan publik khususnya perpajakan menyebutkan bahwa pemungutan pajak pada dasarnya bersifat distortionary yaitu mendistorsi perekonomian berupa adanya deadweight loss (DWL) dimana DWL ini tidak diterima baik oleh Pemerintah maupun agen ekonomi lainnya. Oleh karena itu kita perlu mengetahui tingkat pajak optimum. Secara teroi tingkat pajak yang optimum adalah sistem pajak dengan DWL yang minimum. Selain itu, ada yang menyebutkan pajak yang optimum tergantung pada bagaimana pemanfaatan uang pajak itu sendiri dan dampaknya terhadap masyarakat atau perekonomian.

Mengingat pentingnya pajak baik dilihat dari sisi pemerintah maupun masyarakat, maka sistem pemungutannya harus efektif dan efisien. Sistem pajak yang efektif didefinisikan seberapa besar pajak mampu dikumpulkan dari tax base yang ada. Dalam hal ini belum memperhitungkan tarif pajak. Sedangkan efisiensi/produktivitas pajak diartikan sebagai seberapa besar pajak dapat dikumpulkan dari tax base yang ada pada tingkat tarif pajak tertentu.

Untuk itu perlu diukur kinerja perpajakan baik dari efektivitas maupun produktivitasnya. Sebab, dengan mengetahui tingkat efektivitas dan efisiensi pajak khususnya PPN, selanjutnya dapat ditentukan upaya kebijakan yang diperlukan untuk meningkatkan kinerja perpajakan, khususnya PPN.

\section{METODE PENELITIAN}

\subsection{Data}

Data yang digunakan dalam penelitian ini adalah data sekunder yang diperoleh dari berbagai sumber. Adapun data yang diperlukan adalah produk domestik bruto (PDB), konsumsi rumah tangga, pengeluaran pemerintah, 
Kajian Ekonomi dan Keuangan, Volume 15 No. 1 Tahun 2011

penerimaan PPN, PPh, dan jenis pajak lainnya. Dalam penelitian ini tidak menghitung efektifitas pajak perdagangan internasional karena keterbatasan data tax base untuk pajak ekspor yaitu ekspor dan tax base untuk bea impor yaitu impor. Data yang digunakan adalah data periode 1990-2009.

\subsection{Metode Analisis}

Metode yang digunakan dalam penelitian ini adalah metode deskriptif kuantitatif. Untuk menjelaskan kontribusi, efektivitas, dan efisiensi penerimaan PPN digunakan analisis kuantitatif. Metode analisis yang digunakan adalah sebagai berikut :

a. Untuk menghitung kontribusi penerimaan PPN terhadap anggaran belanja negara digunakan rumus sebagai berikut :

Kontribusi PPN dalam belanja negara $=\frac{(\text { penerimaan PPN })}{\text { Belanja Negara }} \times 100$

b. Untuk menghitung tingkat efektivitas penerimaan PPN diukur menggunakan rasio berikut (Hossain, 1995):

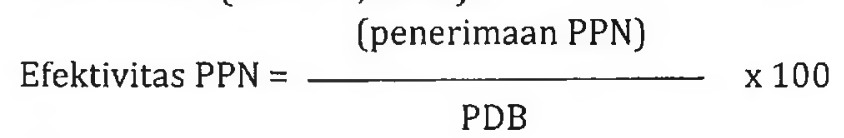

Selain itu, untuk mengukur kinerja pajak PPN, penulis menggunakan indikator efisiensi PPN. Indikator efisiensi PPN terdapat dua jenis indikator yaitu rasio produktivitas pajak pertambahan nilai (VAT productivity ratio) dan rasio efisiensi-c (c-efficiency ratio) (Bird, 2006). Rasio produktivitas PPN mengukur seberapa besar dari produk domestik bruto dapat dikumpulkan pada setiap satu persen peningkatan tarif PPN. Namun indikator ini mempunyai kelemahan karena pajak PPN merupakan pajak atas konsumsi dan bukan pajak produksi. Oleh karena itu, untuk mengukur efisiensi PPN lebih tepat menggunakan c-efficiency ratio. Ukuran ini lebih akurat karena tax base yang digunakan adalah konsumsi domestik dan bukan produksi domestik. Rumus yang digunakan untuk menghitung cefficiency ratio sebagai berikut (Bird, 2006) :

$$
\begin{gathered}
\text { CER }=\frac{\text { (penerimaan PPN/konsumsi nasional) } \times 100}{\text { Tarif PPN }} \\
\text { dimana }: C E R=c-\text { efficiency ratio }
\end{gathered}
$$

Data yang digunakan adalah data nominal baik untuk Produk Domestik Bruto (PDB) maupun konsumsi nasional. Periode kajian dalam tulisan ini adalah tahun $1984-2009$. 
c. Untuk mengetahui faktor penentu PPN digunakan model sebagai berikut :

$$
\begin{aligned}
& \text { PPN }=\alpha+\beta_{1} \text { Kons }+\beta_{2} \text { PengelPem }+\beta_{3} \text { Dummy }+\beta_{4} M+\varepsilon \\
& \text { Dan model yang akan diestimasi adalah : } \\
& \text { DLnPPN }=\alpha+\beta_{1} \text { DLnKons }+\beta_{2} \text { LnPem }+\beta_{3} \text { Dummy } 84+\beta_{4} \operatorname{LnM}(-1)+\varepsilon \\
& \text { dimana LnPPN : } \log \text { PPN } \\
& \text { LnKons : : log konsumsi rumah tangga } \\
& \text { LnPem : : log pengeluaran pemerintah } \\
& \text { Dummy84 : dummy variabel tahun } 1984 \\
& \text { LnM(-1) : : log impor pada tahun sebelumnya }
\end{aligned}
$$

Model regresi yang digunakan dalam penelitian ini menggunakan variabel penjelas/peubah adalah konsumsi rumah tangga/swasta, konsumsi pemerintah, impor tahun sebelumnya. PPN dipungut dari setiap pembelian/konsumsi barang yang dilakukan oleh para pelaku ekonomi baik individu, swasta, maupun pemerintah. Oleh karena itu, tingkat penerimaan PPN ditentukan oleh tingkat konsumsi rumah tangga dan konsumsi pemerintah (asumsi tarif PPN tetap). Impor tahun lalu dapat mempengaruhi penerimaan PPN tahun ini karena adanya pengembalian pembayaran PPN bagi importir yang melakukan proses produksi lanjutan dengan tujuan ekspor.

Metode estimasi yang digunakan adalah ordinary least square (OLS) linear dengan mengubah nilai variabel ke dalam log kecuali dummy variabel. Konsumsi rumah tangga diharapkan dapat meningkatkan penerimaan PPN sehingga koefisien konsumsi diharapkan positif. Demikian juga dengan konsumsi pemerintah diharapkan mempunyai dampak positif terhadap penerimaan PPN. Dummy84 adalah variabel untuk dapat membedakan adanya pengaruh perubahan UU PPN yang diterbitkan tahun 1984. Sedangkan impor pada tahun sebelumnya diharapkan mempunyai tanda negatif karena adanya restitusi atas kegiatan impor barangbarang yang kemudian akan diekspor. Model regresi yang digunakan adalah dalam bentuk logaritma. Hal ini untuk mengatasi permasalahan ekonometrika yang sering muncul bila menggunakan data nominal dalam jumlah sangat besar seperti satuan miliar atau triliunan. Selain itu, dengan menggunakan model log, koefisien parameter secara otomatis menunjukkan elastisitas variable tersebut.

\section{HASIL DAN PEMBAHASAN}

\subsection{Perkembangan Penerimaan Perpajakan}

Perkembangan penerimaan keseluruhan jenis pajak menunjukkan kecenderungan meningkat tipis pada periode 1984-1996 dan setelah itu terjadi peningkatan penerimaan pajak nominal yang signifikan setelah periode tersebut. Tax ratio di Indonesia dibandingkan dengan di negara-negara maju memang lebih 
rendah. Selain disebabkan perbedaan dalam administrasi perpajakan, perbedaan tersebut mungkin disebabkan perbedaan dalam definisi tax ratio. Pertama, tax ratio di Indonesia selama ini tidak memperhitungkan komponen pajak daerah. Selain itu, cakupan tax ratio hanya meliputi jenis pajak yang dipungut pemerintah pusat dan tidak termasuk komponen penerimaan sumber daya alam (royalti SDA). Apabila pajak daerah dan komponen penerimaan SDA (royalti) diperhitungkan dalam tax ratio maka angka tax ratio di Indonesia lebih tinggi.

Pada tahun 1984 tax ratio yang hanya memperhitungkan komponen pajak mencapai 5,3 persen sedangkan rasio penerimaan dalam negeri dimana komponen penerimaan SDA dan hibah dimasukkan mencapai angka yang jauh lebih besar yaitu 17,1 persen. Hal ini menunjukkan kondisi peran penerimaan SDA yang sangat besar dan kinerja perpajakan yang masih relatif rendah. Perkembangan sampai tahun 2009 menunjukkan perbaikan kinerja perpajakan dimana tax ratio (hanya penerimaan pajak) menunjukkan angka 11 persen, naik lebih dari dua kali lipat dibandingkan tahun 1984. Sebaliknya kinerja penerimaan dalam negeri (termasuk penerimaan SDA dan hibah) menunjukkan penurunan menjadi 15,1 persen. Hal ini menunjukkan semakin besarnya penerimaan perpajakan dan semakin menurunnya penerimaan non-perpajakan. Perbaikan ini juga dapat dilihat dari semakin kecilnya gap antara rasio penerimaan negara dan hibah terhadap PDB dengan rasio pajak terhadap PDB.

\section{Grafik 3.1.}

Tax Ratio (dalam persen)

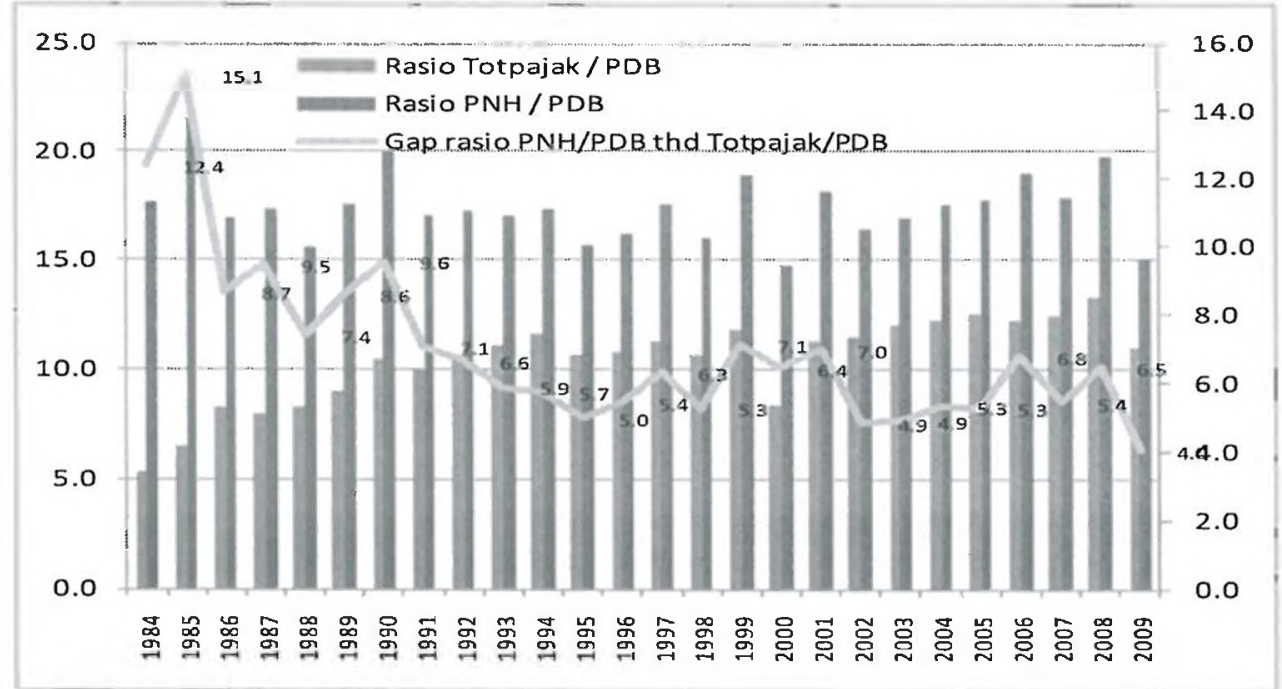

Sumber : Kementerian Keuangan 
Salah satu jenis pajak yang menjadi perhatian dalam tulisan ini adalah pajak pertambahan nilai (PPN). PPN dikenakan atas penyerahan barang/jasa kena pajak pada setiap proses produksi yang menimbulkan nilai tambah. Salah satu tax base pengenaan PPN adalah berapa besar produksi dari suatu negara, sehingga ukuran efektivitas penerimaan PPN diukur dengan membandingkan penerimaan PPN dengan produk domestik bruto (PDB). Ukuran yang lebih akurat adalah berapa besar konsumsi masyarakat dan pemerintah suatu negara.

Grafik 3.2 menunjukkan perkembangan PDB, konsumsi nasional dan penerimaan PPN. Grafik ini menunjukkan bahwa perkembangan penerimaan PPN tergantung pada tingkat perkembangan perekonomian suatu negara. Apabila perekonomian suatu negara berkembang maka kegiatan produksi dan konsumi meningkat sehingga terdapat potensi untuk meningkatkan penerimaan PPN. Pada tahun 1984, PDB hanya mencapai Rp.89,9 triliun dan konsumsi nasional Rp. 63,2 triliun telah berhasil dikumpulkan PPN sebesar Rp.873 miliar; yaitu 1,4 persen konsumsi nasional. Pada tahun 2009 ketika PDB mencapai Rp. 5613 triliun dan konsumsi nasional Rp.3718 triliun (66\%), penerimaan PPN mencapai Rp.193 triliun; 5,2 persen konsumsi nasional. Angka ini naik hampir 4 kali lipat dibanding tahun 1984.

Grafik 3.2.

Perkembangan PDB, Konsumsi Nasional dan Penerimaan PPN (dalam miliar Rp)

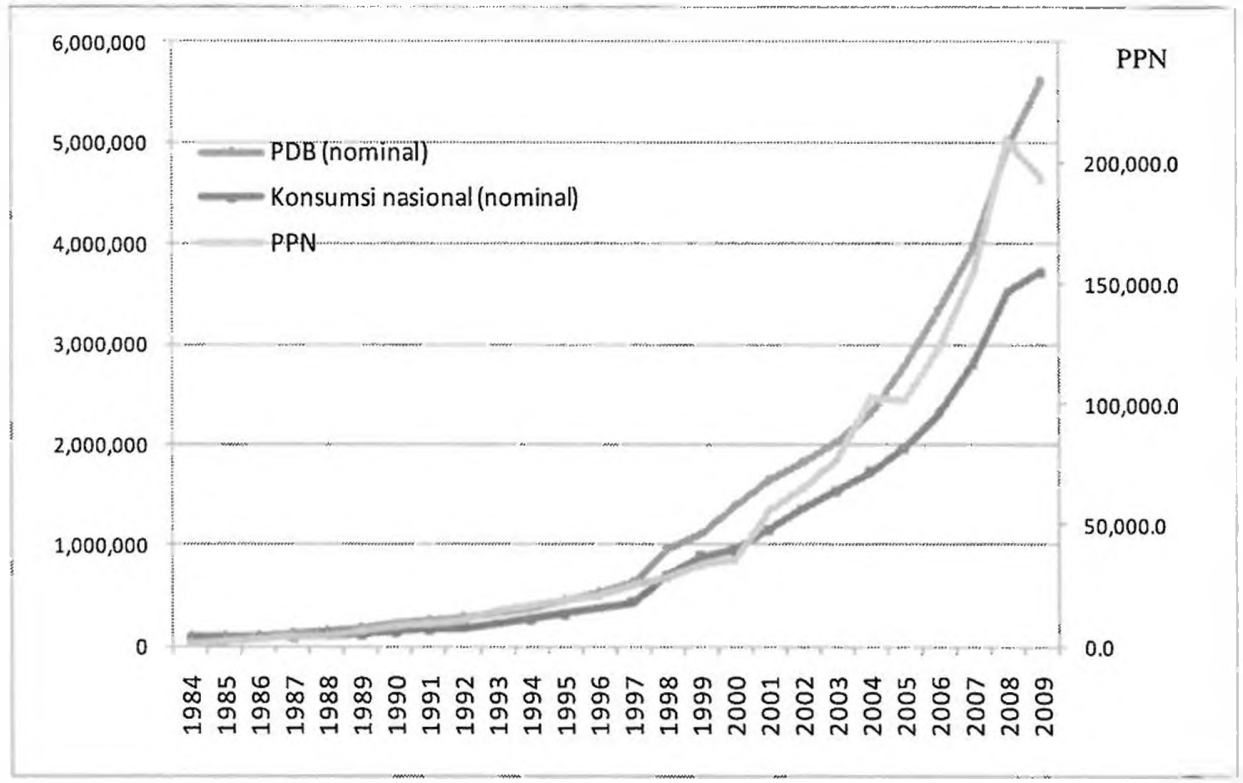

Sumber: WDI online dan Kementerian Keuangan 
Penerimaan PPN tidak semata ditentukan oleh tingkat perkembangan perekonomian. Hal ini ditunjukkan pada tahun 2005 dan 2009 dimana terjadi penurunan penerimaan PPN secara nominal pada saat PDB dan konsumsi nasional meningkat secara nominal dan pertumbuhan ekonomi menunjukkan angka positif. Sebaliknya pada tahun 1998, ketika terjadi krisis moneter di wilayah Asia dan pertumbuhan ekonomi Indonesia mencapai angka negatif $(-13 \%)$, justru penerimaan PPN mengalami peningkatan secara nominal. Dengan demikian, pertimbangan perkembangan ekonomi semata bukan merupakan faktor penentu penerimaan PPN. Faktor politik ekonomi dan faktor struktural ikut mempengaruhi penerimaan PPN (Aizenman dan Jinjarak, 2005).

\subsection{Kontribusi Pajak Pertambahan Nilai}

Kontribusi penerimaan PPN terhadap total penerimaan pajak mengalami fluktuasi selama periode 1984-2009. Pada periode 1984-1989, peran PPN terhadap total penerimaan pajak mencapai rata-rata per tahun 33,7 persen, dan naik menjadi 34 persen pada periode 1990-an, dan selanjutnya menurun pada periode 20012009. Sebaliknya, peran PPh justru mengalami peningkatan terus menerus dari tahun 1984 yang mencapai 34,9 persen menjadi 49 persen pada tahun 2009. Kondisi ini sedikit berbeda dengan kondisi negara berkembang pada umumnya dimana peran pajak tidak langsung (seperti PPN) relatif lebih besar dibandingkan pajak langsung (seperti PPh).

\section{Grafik 3.3}

\section{Peran PPN dan PPh Terhadap Total Penerimaan Perpajakan (dalam persen)}

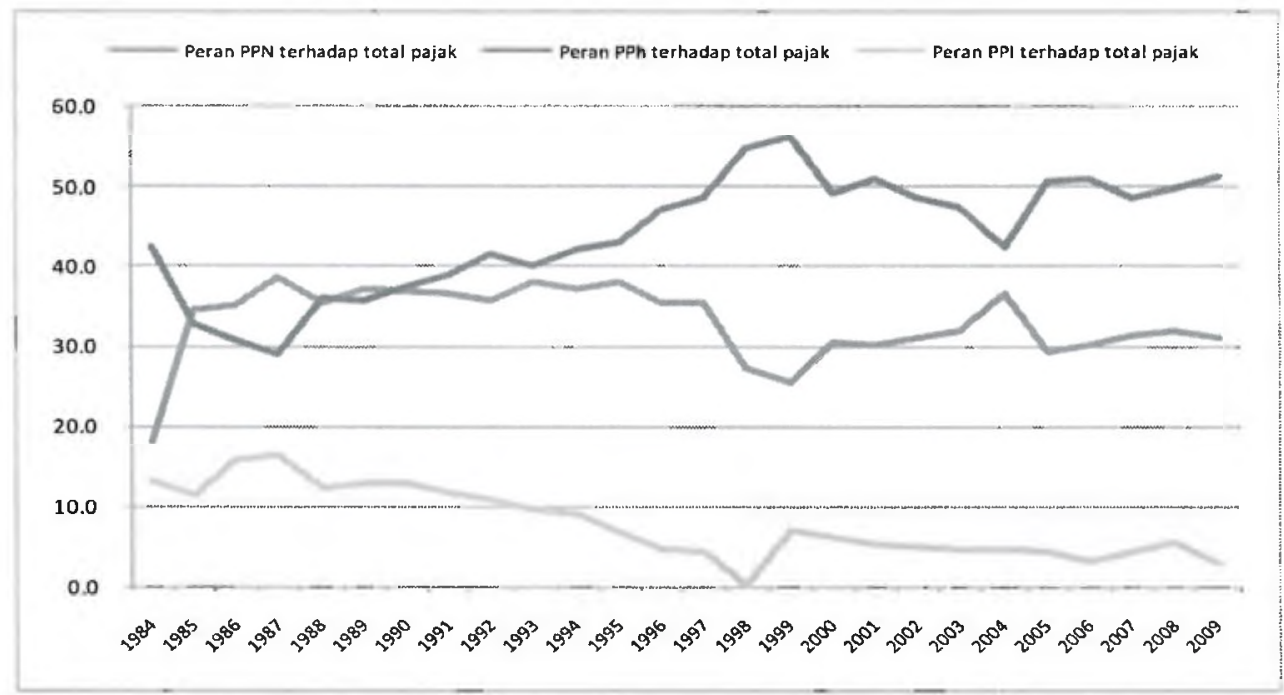

Sumber : Kementerian Keuangan 
Selanjutnya, peran pajak perdagangan internasional semakin menurun sejalan dengan era globalisasi dan perdagangan bebas. Berbagai penurunan tarif/penghapusan hambatan tarif/bea masuk/bea keluar merupakan penyebab menurunnya penerimaan pajak perdagangan internasional. Secara grafik, trend peran PPN dan PPI cenderung menurun, sedangkan trend peran PPh menunjukkan kecenderungan meningkat.

Secara umum, peran perpajakan baik PPh maupun PPN dalam membiayai anggaran belanja negara menunjukkan perkembangan yang sama kecuali tahun 1997 dan 2004-2006. Kecenderungan lainnya adalah peran PPN dalam membiayai anggaran belanja negara lebih rendah dibandingkan PPh. Kontribusi penerimaan PPN dalam membiayai anggaran belanja negara menunjukkan peningkatan pada periode 1984 sampai dengan 1995 dari 5,3 persen menjadi 28,4 persen dan selanjutnya menurun drastis hingga mencapai 6,6 persen pada tahun 1999. Penurunan ini disebabkan semakin besarnya anggaran belanja negara untuk mengatasi krisis ekonomi yang terjadi pada tahun 1997. Seiring dengan pulihnya perekonomian dan menurunnnya defisit anggaran, peran PPN dalam membiayai anggaran negara meningkat kembali sampai tahun 2004.

Dibandingkan dengan PPh, peran PPN dalam membiayai anggaran belanja negara masih lebih rendah selama periode 1987-2009. Kinerja PPN dalam membiayai anggaran negara sama dengan peran PPN dalam struktur perpajakan nasional dimana peran PPh menunjukkan peran yang lebih besar. Kondisi ini mengindikasikan kinerja PPN belum menunjukkan peningkatan yang signifikan sebagaimana dialami negara berkembang, yaitu makin pentingnya peran pajak tidak langsung (seperti PPN).

Secara rata-rata, peran PPN dalam membiayai anggaran negara mengalami peningkatan dari 14,5 persen pada periode $1984-1990$ menjadi 20,2 persen pada periode 2001-2009. Namun peningkatan ini masih lebih rendah dibandingkan $\mathrm{PPh}$ yang mengalami peningkatan dari 14,6 persen periode 1984-1990 menjadi 31,3 persen pada periode 2001-2009. 
Grafik 3.4.

Kontribusi Penerimaan PPN dan PPh Dalam Membiayai Belanja Pemerintah (dalam persen)

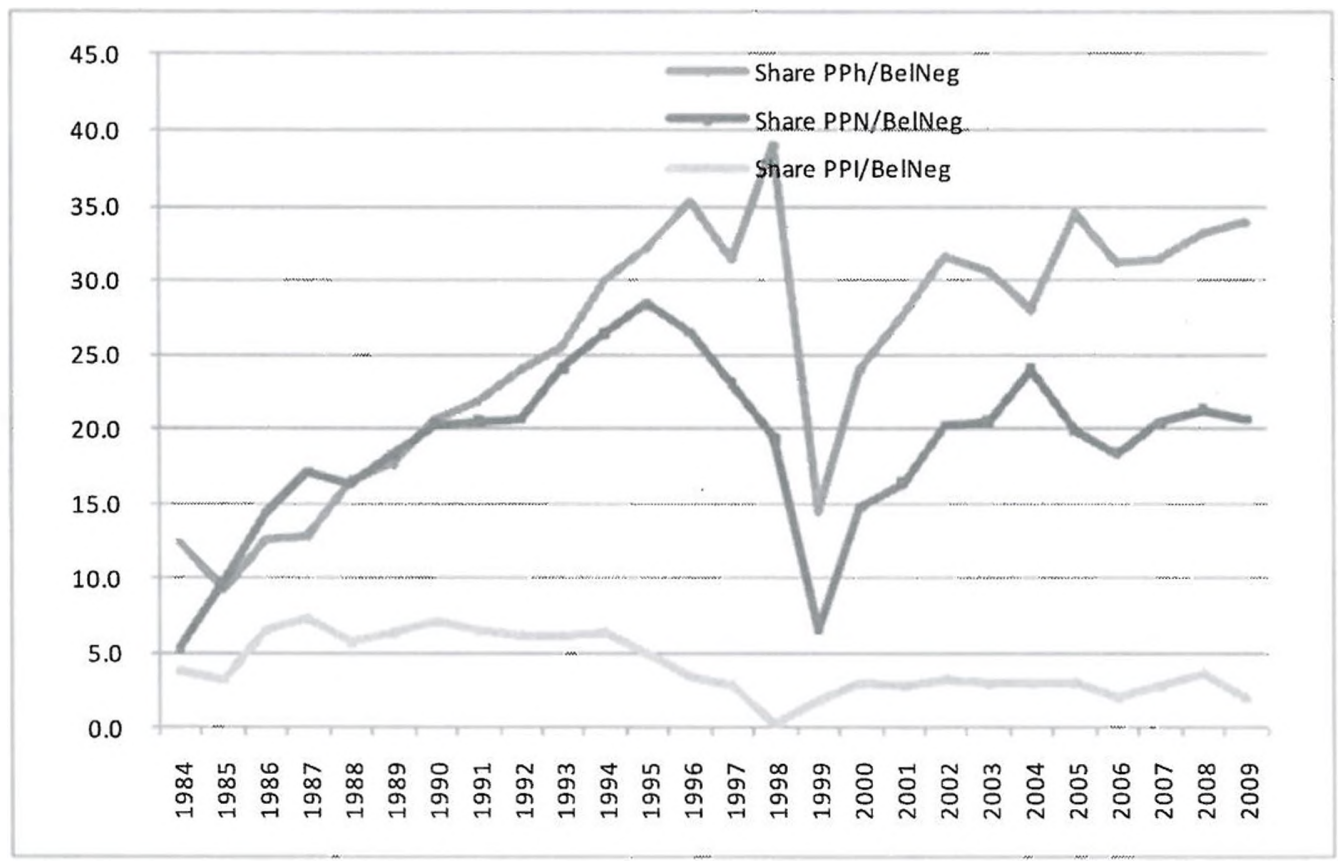

Sumber : Kementerian Keuangan

\subsection{Efektivitas dan Efisiensi Penerimaan PPN}

Setelah dilihat kinerja PPN terhadap total penerimaan pajak dan kontribusinya dalam membiayai anggaran belanja negara dibandingkan pajak lainnya terutama PPh, berikutnya akan dijelaskan kinerja PPN. Ada beberapa ukuran kinerja yang dapat digunakan seperti efektivitas dan efisiensi/produktivitas. Efisiensi dapat dilihat dari sisi produksi (PDB) maupun konsumsi (konsumsi nasional). Sebelum membahas indikator tersebut disajikan perkembangan nominal penerimaan PPN, PPh dan pajak perdagangan internasional. Grafik 3.5 memperkuat temuan diatas bahwa penerimaan PPN masih lebih rendah daripada PPh, padahal kontribusi konsumsi dalam komponen PDB sangat dominan.

Untuk mengukur efektivitas PPN digunakan rasio penerimaan PPN terhadap produk domestik bruto. Dengan mengetahui efektivitas ini, dapat diketahui seberapa besar pajak PPN dapat dikumpulkan dari produksi nasional. Grafik 3.2 menunjukkan bahwa peningkatan PDB selalu diikuti dengan peningkatan penerimaan PPN, sesuatu yang wajar mengingat tax base-nya juga meningkat. Pada tahun 1984, tingkat efektivitas PPN hanya mencapai 1 persen yang berarti hanya 1 
persen dari total produksi nasional yang dapat dikumpulkan sebagai penerimaan PPN. Tingkat efektivitas meningkat pada tahun 2008 menjadi 4,2 persen sebelum turun lagi tahun 2009 ke level 3,4 persen.

Grafik 3. 5.

Perkembangan Penerimaan Pajak (dalam miliar rupiah)

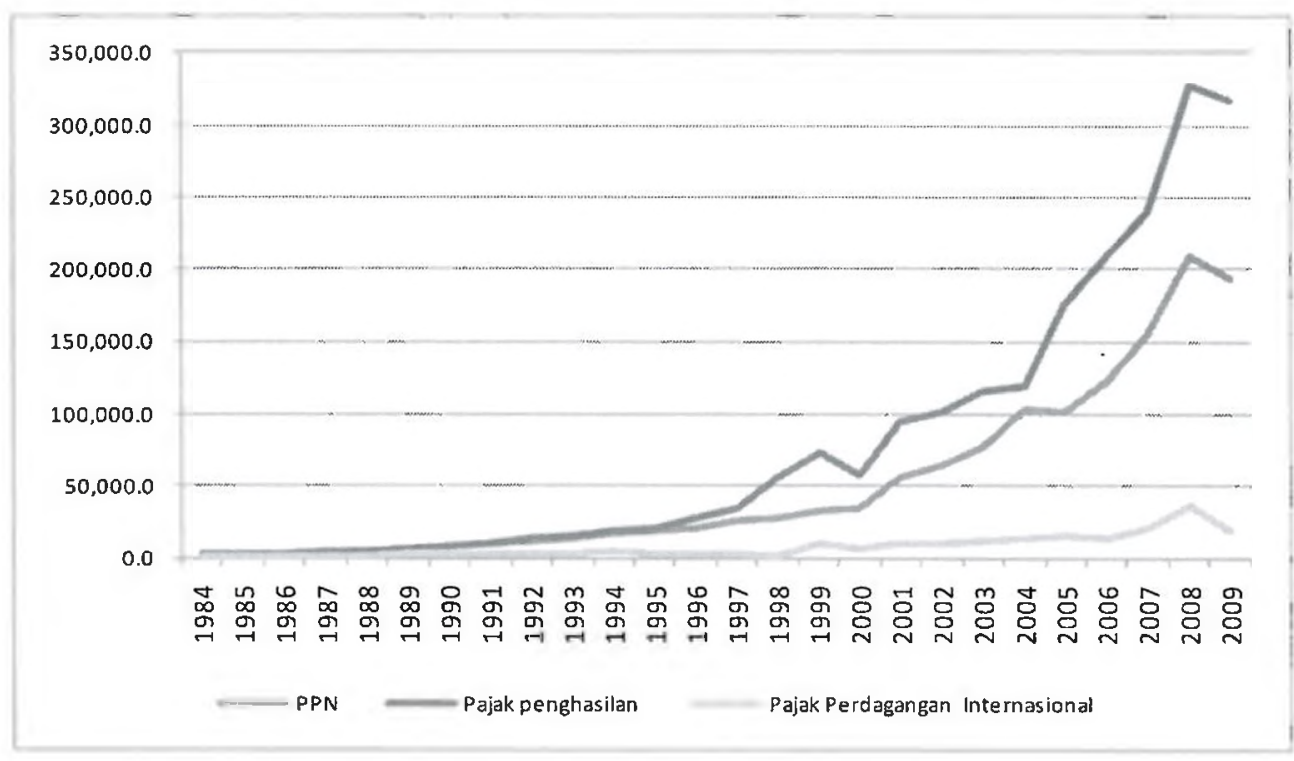

Sumber : Kementerian Keuangan

Peningkatan efektivitas PPN terjadi pada periode 1984-1994, periode 20002004 dan tahun 2008. Tingkat efektivitas pada periode pertama (1984-1994) meningkat dari 1 persen menjadi 4,3 persen yang disebabkan salah satunya adanya perubahan kebijakan perpajakan yang signifikan melalui perubahan UU perpajakan yaitu salah satunya mengganti pajak penjualan (PPn) menjadi pajak pertambahan nilai (PPN). Sedangkan tingkat efektivitas pada periode kedua (2000-2004) meningkat dari 2,5 persen menjadi 4,5 persen. Salah satu sebabnya adalah adanya reformasi perpajakan yang gencar dilaksanakan khususnya perbaikan sistem administrasi perpajakan Hal ini diperkuat hasil studi Brondolo et.al (2008) mengenai reformasi administrasi perpajakan di Indonesia yang menemukan bahwa reformasi administrasi perpajakan telah berkontribusi pada peningkatan penerimaan pajak dan perbaikan iklim investasi.

Selain peningkatan efektivitas PPN, kondisi sebaliknya terjadi pada tahun 1997 dan 2009 yang menunjukkan penurunan efektivitas. Hal ini mungkin disebabkan dampak krisis moneter tahun 1997 dan krisis ekonomi tahun 2008. Namun secara nominal, penurunan ini lebih disebabkan pertumbuhan ekonomi 
yang negatif pada tahun 1997 dan bukan disebabkan penurunan penerimaan PPN sebagaimana ditunjukkan pada grafik 3.4.

Dengan kinerja efektivitas yang fluktuatif menggambarkan dampak reformasi perpajakan yang dimulai tahun 2001 belum menunjukan hasil yang konsisten khusus untuk jenis PPN. Selain itu kebijakan seperti pemberian kebebasan pembayaran PPN untuk jenis komoditas tertentu juga mempengaruhi efektivitas PPN. Adapun peningkatan tipis tax ratio disumbang oleh perbaikan kinerja jenis pajak lainnya terutama pajak penghasilan (PPh).

Ukuran lain yang dapat digunakan untuk mengukur kinerja pajak PPN adalah dengan menghitung produktivitas PPN, yang didefinisikan sebagai rasio penerimaan PPN terhadap PDB dibagi dengan tarif pajak PPN. Produktivitas PPN mengukur tingkat prosentase PDB yang dapat dikumpulkan dari setiap satu persen kenaikan tarif PPN (Bird, 2006). Namun indikator ini tidak tepat digunakan sebagai ukuran kinerja PPN karena PPN dikenakan pada konsumsi dan bukan pada produksi. Oleh sebab digunakan indikator efisiensi/produktivitas dari sisi konsumsi nasional (c-efficiency ratio).

Grafik 3.6.

Kinerja Penerimaan PPN

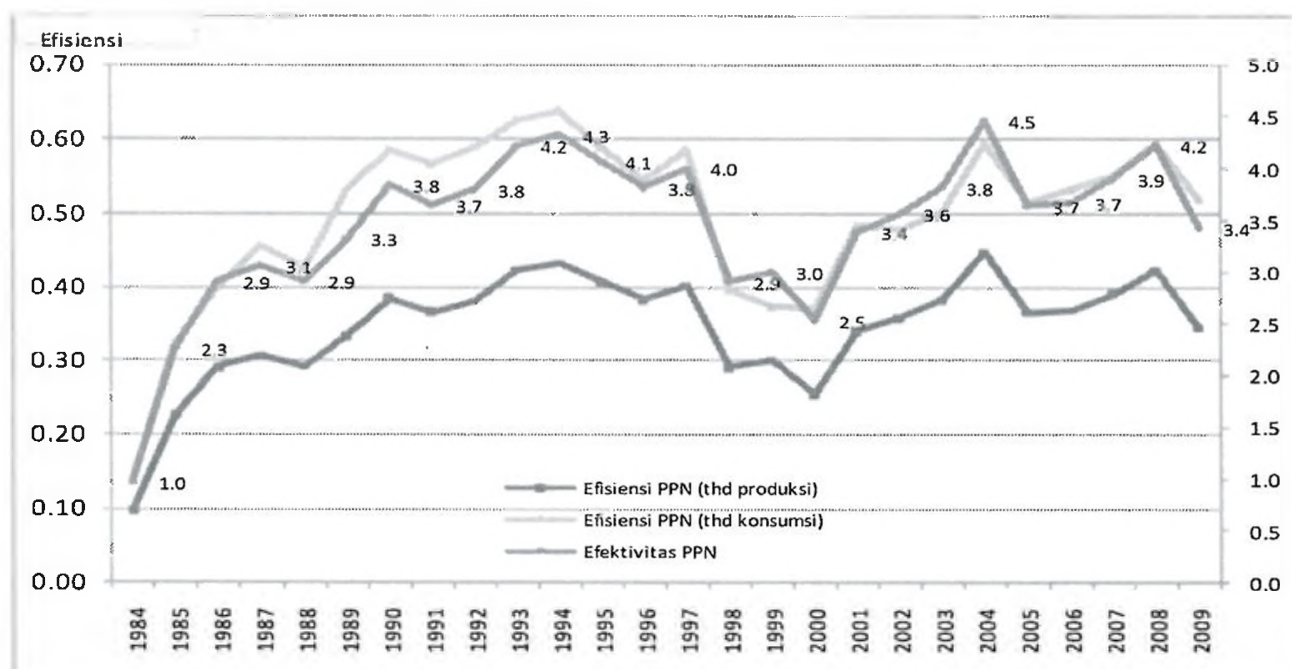

Sumber : WDI online dan Kementerian Keuangan

Rasio efisiensi konsumsi PPN diukur sebagai rasio penerimaan PPN terhadap total konsumsi dibagi dengan tarif PPN. Berdasarkan ukuran tersebut, efisiensi PPN pada tahun 1984 mencapai 0,14 dan meningkat pada tahun 2009 menjadi 0,52. Pola perubahan efisiensi PPN (konsumsi) mirip dengan pola perubahan efektivitas PPN. Tingkat efisiensi tertinggi di capai pada tahun 1994 sebelum krisis ekonomi melanda Asia pada tahun 1997. Pada tahun 1994, tingkat efisiensi 
konsumsi PPN mencapai 0,64. Setelah tahun 1994, penurunan efisiensi konsumsi PPN terjadi pada tahun 2000 dengan tingkat efisiensi sebesar 0,37 .

Perbandingan efisiensi konsumsi PPN antara periode 1984-1990, 1991-2000, dan 2001-2009 menunjukkan secara rata-rata tahunan tidak ada peningkatan efisiensi. Pada periode 1991-2000 dan periode 2001-2009 tingkat efisiensi konsumsi PPN stabil yaitu 0,53. Peningkatan efisiensi hanya terjadi dari periode pertama ke periode kedua.

Perhitungan rasio efisiensi konsumsi PPN tersebut berdasarkan angka realisasi penerimaan PPN. Di dalam prakteknya terutama dinegara-negara berkembang, terdapat kebijakan perpajakan PPN yang bersifat mengurangi/menghindari pengenaan PPN. Dengan berbagai argumentasi dan kemudahan administrasi, sistem PPN di negara berkembang pada umumnya membebaskan/mengecualikan sebagian kegiatan ekonomi tertentu dari pengenaan PPN (Mackenzie, 1991). Kebijakan tersebut dapat berupa exemption, pengurangan tarif maupun zero-rating. Pembebasan/pengurangan ini seharusnya diperhitungkan dalam prosedur yang digunakan untuk memperkirakan tax base. Dengan mengasumsikan exemption rate sebesar 34 persen (Marks dalam Brondolo et.al, 2008) dan tarif sebesar 10 persen, maka potensi penerimaan PPN yang diperoleh seharusnya lebih besar dibandingkan dengan realisasi penerimaan PPN (lihat lampiran).

Pada tahun 1984 potensi PPN yang dapat dikumpulkan seharusnya sebesar Rp4,2 triliun namun realisasinya hanya sebesar Rp.0,9 triliun ( $21,4 \%$ dari potensi). Demikian juga pada periode setelah 1984, realisasi penerimaan PPN selalu lebih rendah daripada potensi yang dapat dikumpulkan. Dari tahun 1984 sampai dengan 1997, gap antara potensi dan realisasi relatif rendah, namun setelah tahun 1997 gap cenderung semakin besar.

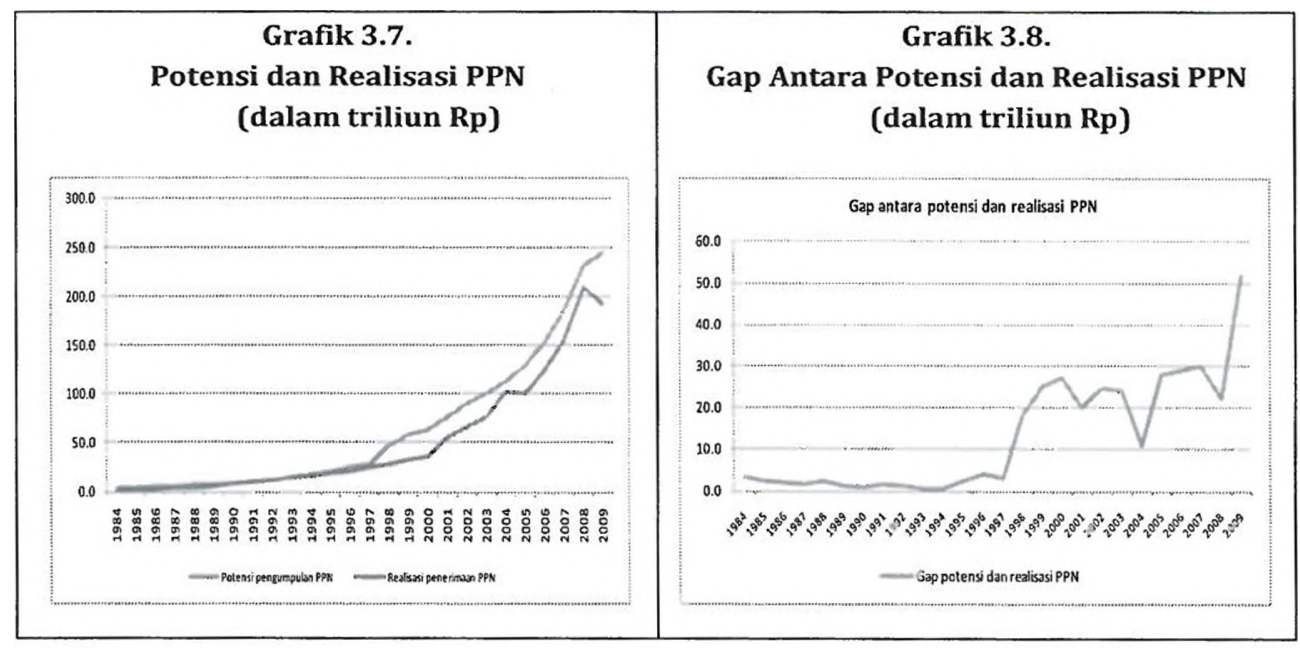

Sumber : WDI online dan Kementerian Keuangan 
Angka gap tersebut dengan mengasumsikan tingkat kepatuhan (compliance rate) 100 persen. Apabila tingkat kepatuhan lebih rendah dari 100 persen maka potensi PPN yang dapat dikumpulkan lebih rendah. Estimasi perhitungan penerimaan PPN dapat dilakukan dengan menghitung potensi penerimaan PPN dengan tingkat kepatuhan (compliance rate). Berdasarkan penjelasan tersebut, upaya peningkatan penerimaan PPN dapat dilakukan melalui peningkatan tarif, pengurangan exemption rate, dan peningkatan compliance rate. Dengan memperbaiki dari sisi penerimaan perpajakan maka kinerja penerimaan PPN dapat meningkat.

\subsection{Faktor-faktor penentu Penerimaan Pajak Pertambahan Nilai}

Setelah membahas mengenai kinerja penerimaan PPN diatas, maka pada bagian berikutnya akan dibahas hasil perhitungan estimasi OLS mengenai faktorfaktor yang menentukan tingkat penerimaan PPN. Berdasarkan hasil estimasi persamaan regresi dengan menggunakan metode ordinary least square (OLS) diperoleh hasil berikut :

$$
\begin{aligned}
& \text { DLnPPN = 0,473DlnKons + 0,582DlnPem + 0,637D84-0,107DLnM(-1) } \\
& \text { t stat } \quad(2,226) \quad(2,881) \quad(23,087) \quad(-2,855)
\end{aligned}
$$

Adjust $\mathrm{R}^{2}=0,1576$

DW stat $=2,142$

Dalam persamaan tersebut, konsumsi dibedakan antara konsumsi swasta/rumah tangga dengan konsumsi pemerintah. Selain itu, penulis juga menggunakan dummy variable untuk menangkap pengaruh perubahan peraturan PPN. Dari hasil estimasi menunjukkan bahwa konsumsi rumah tangga, konsumsi/pengeluaran pemerintah, dan impor tahun lalu serta perubahan peraturan PPN mempunyai pengaruh yang signifikan terhadap penerimaan PPN.

Pengaruh konsumsi rumah tangga/swasta terhadap penerimaan PPN adalah positif dan signifikan dengan nilai koefisien 0,473. Dengan meningkatnya konsumsi rumah tangga/swasta akan meningkatkan penerimaan PPN. Pengeluaran/konsumsi pemerintah berpengaruh positif dan signifikan terhadap penerimaan PPN dengan koefisien 0,582. Peningkatan pengeluaran pemerintah dapat meningkatkan penerimaan PPN. Selain itu, penerapan peraturan PPN pada tahun 1984 berpengaruh positif terhadap penerimaan PPN. Sebaliknya, impor tahun lalu menunjukkan koefisien negatif dan signifikan terhadap penerimaan PPN. Kondisi ini mungkin menunjukkan bahwa peningkatan impor tahun lalu menurunkan penerimaan PPN tahun ini. Hal ini disebabkan adanya mekanisme pengembalian PPN bagi industri yang melakukan produksi untuk ekspor yang 
menggunakan bahan-bahan impor. Meskipun pengaruhnya negatif, nilai koefisiennya rendah dibandingkan variabel lain yaitu 0.107.

Uji signifikansi parsial masing-masing variabel menunjukkan signifikansi untuk seluruh variabel. Sedangkan nilai koefisien determinasi (adjusted $\mathrm{R}^{2}$ ) 0,1576 menunjukkan bahwa variasi penerimaan PPN sekitar 15,76\% nya dapat dijelaskan oleh variabel-variabel tersebut. Sisanya yaitu sekitar $84 \%$ dijelaskan oleh variabel lain seperti tingkat tarif, kualitas institusi perpajakan, administrasi perpajakan, dan sebagainya. Meskipun adjusted $R^{2}$ kecil namun model tersebut cukup baik dengan melihat signifikansi dan tanda koefisien parameternya. Selain itu, uji autokorelasi menunjukkan tidak adanya autokorelasi yang ditunjukkan dengan nilai DW stat sebesar 2,14. Nilai ini cukup untuk menunjukkan tidak adanya autokorelasi.

Hasil estimasi tersebut sesuai dengan studi Bogetic dan Hasan (1993) yang mendapatkan bahwa variabel yang menentukan kinerja penerimaan PPN adalah tarif PPN, tax base, dan tingkat dispersi. Studi tersebut menggunakan data cross section 34 negara dan estimasi ordinary least square (OLS). Hasil mereka menunjukkan variabel tingkat tarif dan tax base berpengaruh positif dan signifikan terhadap penerimaan PPN. Sementara itu, untuk tarif tunggal memberikan dampak terhadap penerimaan PPN yang lebih besar dibandingkan dengan tarif bervariasi.

\section{PENUTUP}

\subsection{Kesimpulan}

Berdasarkan uraian dan analisis tersebut dapat dikemukakan beberapa kesimpulan, sebagai berikut:

1. Peran PPN dalam struktur perpajakan sebesar rata-rata $33 \%$ per tahun, lebih rendah dibandingkan PPh yang mencapai 47\%. Namun demikian, dibandingkan dengan pajak lainnya, peran penerimaan PPN lebih tinggi. Kontribusi penerimaan PPN dalam membiayai belanja pemerintah sebesar rata-rata 19\% per tahun, lebih rendah dibandingkan PPh yang mencapai 25,4\%.

2. Tingkat efektifitas penerimaan PPN mencapai rata-rata $3,5 \%$ setiap tahun, lebih rendah dibandingkan tingkat efektifitas $\mathrm{PPh}$ yang rata-rata per tahun mencapai $5,3 \%$. Sedangkan tingkat efisiensi yang diukur dari $C$-efficiency ratio menunjukkan efisiensi rata-rata per tahun sebesar 0,50 yang berarti setiap kenaikan 1 persen tarif PPN akan menghasilkan tambahan penerimaan PPN sebesar 0,50 persen dari konsumsi nasional.

3. Konsumsi rumah tangga, swasta dan pengeluaran pemerintah mempunyai pengaruh positif dan signifikan terhadap penerimaan PPN. Demikian juga perubahan peraturan berdampak positif terhadap penerimaan PPN. Sebaliknya impor mempunyai dampak negatif dan signifikan terhadap penerimaan PPN. 
Hal ini disebabkan adanya restitusi/pengembalian pajak atas impor yang telah dilakukan bila impor tersebut akan digunakan untuk kegiatan ekspor. Impor tahun lalu dapat diajukan pengembalian pada tahun berikutnya.

\subsection{Saran}

1. Peran PPN dalam struktur perpajakan dan dalam membiayai belanja negara masih dapat ditingkatkan mengingat base pengenaan PPN yang cukup luas. Peningkatan penerimaan PPN dapat dilakukan melalui peningkatan dan perbaikan administrasi perpajakan guna meningkatkan tingkat kepatuhan wajib pajak (compliance rate). Selain itu, dapat dilakukan melalui pengurangan exemption rate. Pemerintah perlu lebih selektif menentukan jenis-jenis produk dan kegiatan ekonomi yang dikecualikan dari kewajiban pembayaran pajak PPN.

2. Demikian halnya dengan tingkat efektivitas yang masih rendah dibandingkan PPh, maka tingkat efektivitas dan efisiensi PPN juga dapat ditingkatkan. Kebijakan untuk meningkatkan penerimaan PPN dapat ditempuh melalui perbaikan administrasi perpajakan seperti peningkatan efektivitas audit, peningkatan layanan kepada wajib pajak yang dapat meningkatkan kepatuhan wajib pajak, perbaikan sistem sehingga sistem self-assesment dapat dilaksanakan dengan tertib dan benar. Selain itu, kebijakan untuk meminimalkan terjadinya kebocoran penerimaan PPN juga perlu dilakukan dengan meningkatkan sistem pengawasan internal dan eksternal.

3. Mengingat kebijakan exemption (pengecualian pengenaan PPN) dapat berpengaruh terhadap jumlah penerimaan PPN, maka kebijakan tersebut perlu diminimalisir. Kebijakan pembebasan PPN untuk impor yang digunakan untuk ekspor perlu lebih selektif dan pengawasan yang ketat sehingga tidak terjadi penyalahgunaan fasilitas tersebut oleh pihak industri/importir.

\section{Daftar Pustaka}

Aizenman, J dan Jinjarak Y, 2005,"The Collection efficiency of the Value added tax : Theory and international evidence," Department of Economics, UCSC, UC Santa Crus, Agustus, eScolarship University of California.

Bird, R M, 2006, "Is VAT the best way to impose a general consumption tax in Developing Countries", Working Paper 06-18, May, International Studies Programe, Andrew Young School of Policy Studies, Georgia State University.

Bogetic Z dan Hassan F, 1993," Determinants of Value-Added Tax Revenue", Working Papers, October, World Bank.

Brondolo J, et.al, 2008,"Tax Administration Reform and Fiscal Adjustment : The Case of Indonesia (2001-2007)", IMF Working Paper, Mei, IMF. 
Hossain, Shahabuddin M., 1995, "The Equity Impact of the Value-Added Tax in Bangladesh", IMF Staff Papers, Vol. 42, No. 2 (June 1995), Washington DC.

International Monetary Fund Institute, 1999, "Forecasting the Fiscal Accounts", Chapter X in Workshops on Financial Programming and Policy, p. 6.

Lindholm, Richard W., 1970, "The Value Added Tax: A Short Review of the Literature", Journal of Economic Literature, Vol. 8, No. 4 (Dec., 1970), p. 1179.

Mackenzie, CA, 1991," Estimating the base of the VAT in Developing Countries : The Problem of Exemptios," IMF Working Paper, Februari, IMF.

Marks, Stephen V, (2003)," The Value Added Tax in Indonesia : The Impact of Sectoral Exemptions on Revenue Potential and Effective Tax Rate," Pebruari, Technical Report, Bappenas-USAID.

Nasution, Lokot Zein., (2007), "Analisis Pengenaan Pajak Pertambahan Nilai (PPN) Pada Perbankan Syariah di Indonesia", Kajian Ekonomi dan Keuangan Departemen Keuangan, Volume 11, Nomor 4, Desember 2007, hal. 140.

Shoup, Carl., (1988), "The Value Added Tax and Developing Countries", The World Bank Research Observer, Vol. 3, No. 2 (Jul., 1988), p. 140.

Sukardji, Untung, (2003), "Pajak Pertambahan Nilai", Edisi Revisi, Raja Grafindo Persada, Jakarta. 
Kajian Ekonomi dan Keuangan, Volume 15 No. I Tahun 2011

\section{LAMPIRAN}

\begin{tabular}{|c|c|c|c|c|c|c|c|c|c|c|c|c|c|c|c|c|c|c|c|c|c|c|c|c|c|c|}
\hline \multirow{2}{*}{ Uraian } & \multicolumn{26}{|c|}{ Tahiun } \\
\hline & 1984 & 195 & 1986 & 1987 & 1008 & 1989 & 1900 & 199 & 1992 & 1993 & 1994 & 1985 & 1996 & 997 & 190 & 1990 & 2000 & 20012 & 2002 & 200320 & 200420 & 20052 & $2006 \mid x$ & 200720 & 200320 & \\
\hline POB nomrol (tritun Ap) & 899 & 970 & [02] & 248 & 1.997 & 2066 & 20.9 & 800. & 2224 & 308 & 320 & 4545 & 5226 & 627] & 95886 & .0997] & 1392801, & 1,6463 1 & 1,808 & 2013722 & 2255827 & 274333 & 13392139, & $3,50,999,9$ & $4,591 \mathrm{~A} \mid \mathrm{S}, 6$ & \\
\hline Konsumichthin nsionod (tritun Rp) & $\$ 2$ & $\infty$ & 7487] & $\$ 8$ & 025 & 103 & 3855 & 1616 & 1822 & $m$ & 289: & 365 & 324 & 430:1 & 7022 & 8058 & 947.6 & $1,151,15$ & $\mid 3642$ & $15358: 1 \pi$ & $1729)$ 19, & 1,63342 & 2303280 & 28066.635 & 3525] 3.7. & 7782 \\
\hline & & & & & & & & & -1 & & $\ldots-1$ & 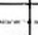 & & - & -1 & $=$ & -1 & & $\ldots$ & -1 & + & - & $\ldots$ & 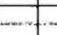 & $\ldots$ & 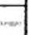 \\
\hline Exention notell) & 0344 & 034 & 034 & 034 & 0.34 & 034 & 034 & 034 & 034 & 034 & 034 & 034 & 034 & 034 & 034 & 034 & 034 & 034 & 034 & 034 & 034 & 034 & 034 & 034 & 034 & 034 \\
\hline Konsumi iubjeat to PPN (trtun RP) & 416 & 448 & 491. & 别 & $67 \mathrm{~A}$ & 739 & 9x! & 1063 & 199.9 & 1465 & 1005 & 2076 & 2550 & 2330 & 462 & 5829 & 685 & 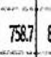 & 8976 & $1,0105: 16$ & BBAA & 1,2919 & 150.218 & 18468:233 & 2379.94 & 466 \\
\hline \multicolumn{27}{|l|}{ 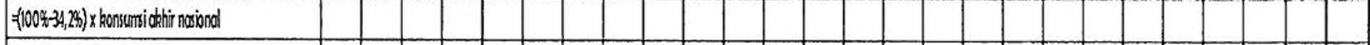 } \\
\hline & & & & & & & & & & & & & & & & & & & $\ldots$ & & & & & & & \\
\hline IGaŕf PPN $(x)$ & 100. & 10.0 & 10.0 & 100 & 0.0 & 10.0 & 100. & 100 & 100 & 10.0 & 10.0 & 100 & 100. & 1000 & 10.0 & 100 & 10.0 & 10.0 & 10.0 & 10.0 & 10.0 & 10.0 & 10.0 & 10.0 & 10.01 & 10.0 \\
\hline Potersipengurpulam PPN & & & & $\mathrm{sct}$ & & 71 & . & $n$ & 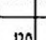 & T & 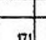 & not & 7 & 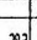 & (1) & + & t & 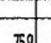 & -1 & T & $\begin{array}{lll}-1 & -1 \\
& -1 & 0\end{array}$ & 1 & & & & \\
\hline & 44 & 4.) & -495 & 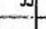 & 4 & it & int & 10,0 & 20 & S.t. & -1 & (2) & 495 & $\Delta 8$ & 804 & 380 & 024 & 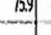 & 898 & 21 & $\mathbb{1} 134$ & {$[2]$} & 820 & 184.t] & $2182^{2}$ & 4.4.7. \\
\hline 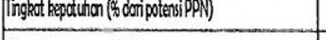 & 200 & 489. & 608 & 69.4 & 648 & 80 & 89.1. & 86.0 & 896 & sal & 970. & 822.2 & 歫 & 890 & 602 & 508 & 505 & $78 \mathrm{~B}$ & 725 & 763 & 5004 & 784 & 80.9 & 8379 & 904 & 809 \\
\hline Etinsipanerimom PPN & 33 & 35 & 39 & .43 & 53 & 58 & 72 & 8) & 95 & 123 & 148 & 166 & BA & 29 & $E_{B}$ & 30.6 & 32 & 50.9 & 598 & 69.6 & 923 & 890 & 1066 & $B B B$ & 19072 & 033 \\
\hline 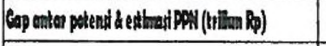 & ON9 & 0.96 & 406 & 40 & LAS & 159 & 496 & 233 & 253 & 236 & 20 & 4,11 & 6.13 & 538 & 2042 & 2109 & 30,15 & 24.963 & 30,34 & $343_{2}^{2}$ & 2410140 & $40,1 3 \longdiv { 4 }$ & $43 \mathrm{AB} 4$ & 47,8340 & 40.104 & |3:35 \\
\hline 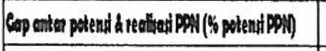 & $2,3,3$ & 21,5 & 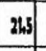 & 2615 & $21 \mathrm{~s}$ & $21 / 5$ & 21,5 & 2,0 & 24 & $s_{1} \mid$ & $B, 3$ & Bas & $x_{1}$ & 19.0 & 44,2 & 47,5 & 4BA & 329 & 33, & 341 & 18,6 & 34 & 29.9 & 25,9 & $\pi, 3 \sqrt{1}$ & B.9.9. \\
\hline Reabcos panerinom PPN & 09 & 22 & 30 & $3:$ & 44 & 60 & 81 & 9. & 10.7 & $B 9$ & 165 & 285 & $20 \mathrm{~A}$ & 62 & an & 331 & 352 & 560 & 652 & $\pi 110$ & $1025 \times$ & 013 & 1300 & $515[2$ & 209.6 & 1931] \\
\hline 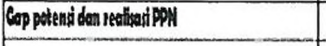 & 33 & 23 & 19 & 10 & 24 & (4) & 10 & 15 & 12 & 0.7 & 05 & 22 & 42 & 31 & 84 & 62 & 게 & 19.9 & 246 & 24.0 & 109 & 20.9 & 20.0 & 301 & 2) & 916 \\
\hline \multicolumn{27}{|l|}{ BFKTNITAS } \\
\hline 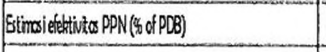 & 36 & 36 & 38. & 35 & 35 & 32. & 34 & 32. & 33 & 37]. & 39 & 37] & 34 & 3] & 27 & 28 & 23 & al| & 33 & 35 & 40. & 32 & 32. & 35 & 39 & 36 \\
\hline 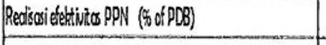 & 10 & 23 & 29 & 31) & 29 & 33 & 38 & 37]. & 38 & 42 & 43. & 4. & 38 & 4.0 & 29 & 30 & 25 & 34. & 36 & 38 & 45 & 37 & 33 & 39 & 42 & 3.A. \\
\hline 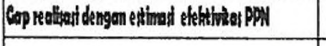 & $2 \pi$ & -14 & 0.4 & .04 & 0.06 & 0.1 & 0.3 & $O A$ & 0.3 & 0.3 & 0,3 & $O A$ & 0.4 & 0.4 & 0.2 & 0.2 & 0.2 & 0.3 & 0.3 & 0,4 & 0.4 & 0.4 & 0.4 & 0.4 & 0.4 . & 0.28 \\
\hline & & & & & & & & & & & & & & & & & & & & & & & & & & \\
\hline \multicolumn{27}{|l|}{ PRODUKTNITAS } \\
\hline 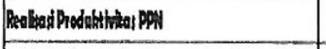 & 0,10 & 0.23 & 0.2 & 0,31 & 0,29 & 0.33 & 0,38 & 0.37 & 0.38 & 0.42 & 0.48 & OAL & 0.38 & 0.40) & 0.29 & 0,30 & 0,3 & 0,34 & 0.36 & 0.316 & 0435 & 0.37 & 0,39 & 0,3910 & 0.420 & 0,34 \\
\hline & & & & & & & & & & & & & & & & & & & & & & & & & & \\
\hline \multicolumn{27}{|l|}{ 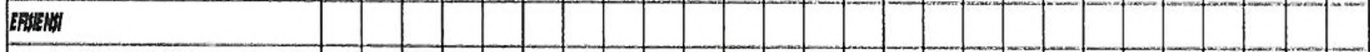 } \\
\hline Ettimsirasio exuitersi (orodulys) & 036 & 036 & 0.38 & 035 & 035 & 032 & 0.34 & 032 & 0.33 & 037 & 039 & 0.37 & 034 & 033 & 02 & 028 & $O B$ & 031 & 033 & 0.50 & 040 & 032 & 032 & 0.35 & 033 & 0.36 \\
\hline 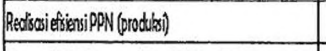 & 0.0 & 0.8 & 028 & 03 & 0.2 & 0.33 & 038 & 0.37 & 038 & $\mathrm{OA2}$ & 0,43 & OAN & 0.38 & 0.0 & 0.2 & 030 & 0.5 & 0.34 & 036 & 038 & 0.45 & 0.37 & 0.37 & 039 & OA2 & 034: \\
\hline 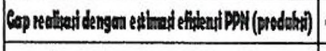 & $-0,2 x$ & 0,14 . & -0.08 . & $-0,04 \cdot$ & 0.06 & 0.01 & 0.08 & 0.04 & 0.05 & 0.03 & 0.03 & 0.04 & 0.04 & 0,04 & 0,02 & 0.02 & 0.02 & 0.03 & 0.003 & 0,040 & 0,040 & 0.08 & 0.05 & 0.040 & 0,040 & 102 \\
\hline & & & & & & & & & & & & & & & & & & & & & & & & & & \\
\hline Etimsirøio trikensi fonsumi) & 0.52 & 02 & 052 & 052 & 0.52 & 052 & 0.52 & 0.50 & 052 & 0.55 & 0.5 & 0.53 & 0.49 & 053 & 037 & 0.35 & 034 & 0.44 & OA4 & 0.45 & 054 & 0.45 & 046 & OA9 & 0.54 & 0.53 \\
\hline 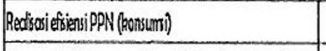 & 0.14 & 021 & 0.40 & 0.46 & 0.43 & 0.5 & 059 & 05 & 059 & 0.63 & 0.64 & 0.59 & 0.55 & 059 & 0.40 & 037 & 033 & 049 & 0.40 & 050 & 0.59 & 05. & 05 & 0.55 & 0.00 & 05 \\
\hline 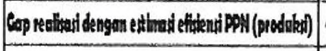 & $-0,38$ & 0,18 & $0,0.12$ & $0.06 \cdot$ & 0.09 & 0.02 & 0.07 & 0.06 & 0.07 & 0.08 & 0.98 & 0.06 & 0.08 & 0.05 & 0,08 & 0.03 & 0.03 & 0.04 & 0.04 & 0,056 & 0,060 & 0.06 & 0.07 & 0.060 & $0.05 \cdot 0$ & \\
\hline & & & & & & & & & & & & & & & & & & & & & & & & & & \\
\hline \multicolumn{27}{|c|}{ 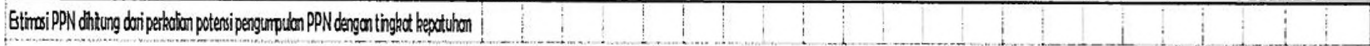 } \\
\hline 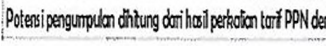 & tengen kx & horsuruin & naxionoly & lyengles & ver of th & enderan & PQN & teth mern & mpothitur & nghe & exemplis & & & & & & & & & & & & & & & \\
\hline
\end{tabular}

Sumber: Perhitungan penulis

\section{Catatan :}

a. Estimasi penerimaan PPN dihitung berdasarkan tingkat kepatuhan yang bersifat sangat kasar.

b. Angka exemption rate berasal dari perhitungan Marks S V dalam Brondolo J et.al (2008). 